Author: R Koen

IN DEFENCE OF PASHUKANISM

ISSN 1727-3781



2011 VOLUME 14 No 4

http://dx.doi.org/10.4314/peli.v14i4.5 


\section{IN DEFENCE OF PASHUKANISM}

R Koen*

\section{Introduction}

Capitalism is in profound and open crisis. The meltdown began in 2008 with the implosion of a host of flagship financial institutions in the most advanced capitalist states, ${ }^{1}$ and continues to this day with the economic decimation of a number of the weaker capitalist states. ${ }^{2}$ The current crisis is so serious that it is equated routinely with that most scary of capitalist crises, the Great Depression of the 1930s, which had placed a question mark over the very existence of the mode of production. Needless to say, the contemporary crisis of capitalism is neither a sudden nor a short-term aberration. For more than a century already, capitalism as a mode of production has been in historic decline, wracked by an ever-deepening contradiction between relations and forces of production, as the former increasingly has become an obstacle to the development of the latter. And the daemon of overproduction which has been ravaging the heartland of capitalism so relentlessly for the last three years has been gnawing away at its constitution for the last thirty years at least. Since the early 1970s, international capitalism has lurched from crisis to crisis, like a drunk who has lost his way. Certainly, it is indisputable that the current crisis is not conjunctural; it is the latest explosion of a bankruptcy which goes to the structural core of the mode of production.

The triumphalism which accompanied the capitalist restorations in the erstwhile Soviet Union and its Eastern European satellites has evaporated. In its stead we see the captains of industry, the lords of finance and the fiscal executives of the biggest capitalist economies scurrying to find ways out of the vice-grip of the crisis.

R Koen. LLM PhD (Cape Town). Senior Lecturer in and Chair of the Department of Criminal Justice and Procedure, Faculty of Law, University of the Western Cape (rkoen@uwc.ac.za)..

These include Lehman Brothers, Merrill Lynch, the American International Group (AIG) and Bear Stearns.

2 The latest victims of the crisis are the so-called PIGS of Europe, namely, Portugal, Ireland, Greece and Spain. 
Unsurprisingly, it is public money which has funded the last three years of capitalist efforts to shore up failing financial institutions and to rescue defaulting national economies. Ordinary working men and women have been saddled with the economic burden of bailing out the system, both in respect of the trillions of dollars of public revenue which have been disbursed to imploding sectors of the capitalist economy and in respect of the years of austerity which they necessarily will be expected to endure. Schumpeter, ${ }^{3}$ writing at a time when the Great Depression and the World War which ensued had precipitated a crisis of the capitalist mode of production which was unprecedented, identified a general "atmosphere of hostility to capitalism", warning that:

The public mind has by now so thoroughly grown out of humour with it as to make condemnation of capitalism and all its works a foregone conclusion.

The current crisis is at least of the same order. And again, as then, public disenchantment with capitalism is palpable, as ordinary citizens realise that it is they who are being made to pay, literally, for the cynical and scandalous excesses of the capitalist class. ${ }^{4}$

It has become evident also that conventional bourgeois economics is unable to comprehend the material basis of the crisis. Both Keynesianism and Monetarism have been paralysed in the face of the explosive contradictions tearing away at the heart of the capitalist mode of production. As the crisis has exposed the poverty of neoliberalism and its deification of the free market, so interest in the Marxist critique of capitalism has waxed. It has been reported widely that demand for and sales of Marx's work, especially Volume 1 of Capital, have increased dramatically as the crisis has taken hold. ${ }^{5}$ In 2009 Hitchens $^{6}$ used "He's Back" as the title of an article on "the current financial crisis and the enduring relevance of Marx". Albeit anecdotal,

Schumpeter Capitalism, Socialism and Democracy 63.

4 See Angus Reid Global Monitor 2008 http://www.angus-reid.com, BBC World Service 2009 http://www.worldpublicopinion.org, De Santis 2009 http://www.humaniteinenglish.com and The Economist $2011 \mathrm{http}: / /$ www.economist.com.

5 See, for example, Connolly 2008 http://www.guardian.co.uk, Boyes 2008 http://business.timesonline.co.uk and NBC News 2009 http://worldblog.msnbc.msn.com.

Hitchens 2009 The Atlantic. 
such developments betoken the objective fact that the possible demise of capitalism is much more real than the alleged death of Marxism, and that the need for a rigorous Marxist critique of capitalism is both necessary and urgent.

The current crisis has placed on the agenda also the interrogation of the legal form. Law is a crucial element of the regulatory structure of capitalism and makes a significant contribution to the reproduction of the social relations of production of the mode of production. The rule of law is the frontispiece of capitalist democracy and is considered to be emblematic of the liberal ideals of liberty and equality. In combination with a culture of human rights, it is deemed to be the route to justice for all. However, the extended crisis of capitalism has placed the rule of law under severe pressure, as increasingly more capitalist states increasingly embrace authoritarianism as part of their endeavours to stem the tide of disintegration. Liberal jurisprudence, wedded as it is to the idealist notion of law as a system of norms, may bemoan and oppose the assault upon civil liberties but is unable to comprehend its material foundation. Much the same may be said of two of the most conspicuous concomitants of the current crisis, namely, the rampant militarism accompanying the "war on terror" in the advanced capitalist world and the flagrant corruption which has become embedded in the very constitution of global capitalism. Both are patently unlawful but are pursued with impunity, leaving liberal jurisprudence foundering because it lacks the analytical resources to apprehend the propinquity between legal relations and capitalist relations. As with bourgeois economics, so with liberal jurisprudence: there never has been a more compelling need to harness the power of the Marxist epistemology to the effort to make sense of the legal dimension of capitalism in general and of the current conjuncture in particular. ${ }^{7}$

It is appropriate at this juncture to comment briefly upon the implications of the arguments presented here for the analysis of the post-apartheid South African social formation. From a Marxist perspective, the primary analytical injunction in this regard is to transcend the notion of exceptionalism which is attributed routinely to the South African "miracle" and to perceive that the demise of apartheid did not entail any fundamental transformation in the socio-economic rudiments of the country. If anything, the political transformation in South Africa has foregrounded the capitalist character of the country, which character had been camouflaged for so long beneath the canopy of institutionalised racism. The point is that there is no good reason to consider that South Africa is somehow qualitatively different from the rest of the capitalist world. The political transformation was not the harbinger of a social revolution and the postapartheid state is by no means a post-capitalist state. Contemporary South Africa is an "ordinary" 
Of course, there are competing Marxist approaches to the law, ranging from law as instrument of class oppression, through law as ideological trickery, to the rule of law as an unqualified human good. ${ }^{8}$ While all of these approaches may illuminate the contours and contradictions of legal relations to a greater or lesser degree, it is submitted that the fundamental task of the Marxist analysis of law is to explain why legal relations take the form they do. In this connection, Miéville ${ }^{9}$ is correct in his proposition that "without a theory of the legal form, the specificity of law itself is impenetrable". Certainly, the niggardly condition of liberal jurisprudence in the face of the contemporary crisis of capitalism is affined closely to its want of a theory of the legal form. Marxism produced such a theory of the legal form already in the first quarter of the twentieth century, with the publication in 1924 of Law and Marxism: A General Theory by the Bolshevik jurist, Evgeny Pashukanis. And it is a central contention of this essay that the general theory of law elaborated by Pashukanis defines best the lineaments of a critique of legal relations within the parameters of classical Marxism.

\section{The need to defend Pashukanism}

In a cynical attempt to dispense with the general theory by dispensing with its author, Pashukanis was liquidated in 1937 by the hatchet men of the Stalinist regime. However, notwithstanding the passage of more than 70 years, the general theory remains vital and Pashukanis continues unsurpassed as the Marxist theoretician of the law. Indeed, it may be asserted with some confidence that no subsequent Marxist jurisprudent has been able to match or even approximate the theoretical

capitalist country, which differs from its counterparts in degree only. And whereas it is not suffering the kind of explosive economic crisis that is battering many of its counterparts, its economic future is tied intimately to the trajectory of the global crisis. Thus, if the Marxist methodology is the key to comprehending the current crisis of capitalism, it is equally exigent for the analysis of post-apartheid South Africa. See Alexander An Ordinary Country for a sustained consideration of this perspective on South Africa.

8 Useful discussions of the variety of Marxist perspectives on the law may be found in Gavigan 1981 Canadian Criminology Forum and Vincent 1993 Journal of Law and Society. Critical consideration is given to some these perspectives in section 3 below.

$9 \quad$ Miéville Between Equal Rights 2. 
insights of Pashukanis and the analytical advances made by him in the materialist comprehension and critique of legal relations. Certainly, his legal conspectus, forged during the heady days of of the proletarian revolution under the Bolsheviks, stands out like a beacon of theoretical rationality in an otherwise decidedly impoverished Marxist legal tableau. And his Law and Marxism, which is concerned to lay bare the hidden constitution of the legal form, deservedly has become a classic of Marxist jurisprudence. The Marxist pedigree of his general theory is evident from the ready acknowledgment by Korsch, one of his early and more austere Marxist critics, that it represents "the only consistent development of the teaching of Karl Marx". ${ }^{10}$

Unsurprisingly, Pashukanis's work has never found favour among non-Marxist legal analysts. ${ }^{11}$ Surprisingly, however, his work has not found especial favour among Marxists either. The potency of his thesis gives it an obvious and, arguably, a legitimate claim to be recognised as the Marxist theory of law and, hence, to have been elevated to the status of conventional Marxist wisdom in the analysis of legal relations. However, quite the opposite has occurred. Despite his theoretical sophistication, Pashukanis remains anathema to and the general theory has been disowned roundly by most jurisprudents, including many who would own to more than a passing knowledge of and commitment to the tenets of Marxism. ${ }^{12}$ Indeed,

As reported by Hayek Law, Legislation and Liberty 181 fn 34.

11 Generally, non-Marxist jurisprudents have given Pashukanis short shrift. The bulk has responded to his general theory of law with the kind of silence which screams rejection or with the kind of token acknowledgement which does the same. Standard text-books on jurisprudence, with few exceptions, tend to ignore him. Most will include a brief section on the Marxist or socialist approach to law, and will focus on the conventional Marxist efforts to inject class content into legal analysis. Pashukanis goes beyond this conventional Marxist approach and attacks the legal form itself. A crucial aspect of his critique of the legal form is his demonstration of its historical contingency. He posits a "lawless" past and anticipates a "lawless" future. The mere thought that law is not a timeless feature of human society is offensive to most lawyers and accounts in large measure, it is submitted, for why Pashukanis has been ignored so resolutely by the legal establishment, including the academic legal establishment. Bourgeois jurisprudence cannot countenance a world without law.

12 Pashukanism did enjoy authoritative status in Bolshevik Russia, but was violently dismantled by the Stalinist regime and consigned to obscurity for more than three decades. There was a revival of interest in Pashukanis in the 1970s amongst Western radicals especially. See Butler Soviet Law 32. He continued to enjoy support amongst some analysts well into the 1980s. See, for example, Melossi and Pavarini The Prison and the Factory, Norrie 1982 International Journal of the Sociology of Law, Sayer The Violence of Abstraction and Jakubowski Ideology and Superstructure. However, these years also witnessed sustained theoretical assaults upon Pashukanism, not least from Western critics who would consider themselves to be Marxists. Reliance upon or reference to his general theory all but ceased in the 1990s and the twentieth 
Pashukanis is nowadays rarely even acknowledged by the new left as a theoretician of any consequence in the Marxist legal oeuvre. The reasons for his sidelining cannot detain us here but are to be found, for the most part, in the deleterious impact of Stalinism upon the Bolshevik heritage and the subsequent ambiguous relationship of Western Marxism to this heritage. The post-1956 demise of Stalinism notwithstanding, Pashukanis's contribution to Marxism, like Trotsky's, has never been properly recovered from the distortions and falsifications of the Stalinist degeneration. At best, Pashukanism may lay claim to being an unconventional Marxist wisdom in things juridical.

This essay has been written from the conviction that the general theory is, according to the ontological and epistemological constituents of classical Marxism, impeccably Marxist in all its essentials and that it indeed does have a valid claim to precedence in the field of Marxist legal theory. The essay is simultaneously and necessarily, therefore, also a defence of Pashukanis. He needs defending and, ironically, more so against his critics on the left than those on the right. The fundamental criticism from the left is simple: that Pashukanis's general theory of law is fatally flawed because it is not a Marxist theory of law proper. Makepeace ${ }^{13}$ goes so far as to assert that "most critics consider it so", that is, that the general theory is unMarxist. In other words, according to Pashukanis's left critics, the general theory cannot withstand scrutiny from a Marxist point of view.

This essay is a rejoinder to the detractors of Pashukanism. It attempts to answer the critics and thereby to refute the charge that the general theory of law is not properly Marxist. It seeks, by riposte, to elaborate an unconditional defence of the general theory. Needless to say, the very notion of an unconditional defence may be objectionable to a goodly number of readers. ${ }^{14}$ However, the writer is convinced that

century closed with Pashukanism being marginalised yet again. However, interest in Pashukanis and his general theory has begun to resurface lately, in the work of such Marxist analysts as Miéville Between Equal Rights and Head Evgeny Pashukanis. Makepeace Marxist Ideology and Soviet Criminal Law 96-97.

14 Unconditional defences routinely invite a charge of partisanship. Two points to counter such a charge must suffice here. Firstly, every defence is partisan by definition. However, such inherent partisanship cannot constitute a ground upon which to invalidate the defence as an analytic. 
the general theory is of sufficient moment to merit such a defence from a Marxist perspective. What is indubitable, in this connection, is that contemporary Marxist jurisprudence is the poorer for its shabby treatment of Pashukanis. Therefore this essay is perforce in part a contribution to the belated renascence of the classical Marxist jurisprudence of which Pashukanis is, after Marx and Engels, the most creative and truest representative.

If this period clamours for a Marxist critique of capitalist relations, it clamours also for a Pashukanist critique of legal relations. If this is the time to recover the analytical capacities of classical Marxism, it is the time also to retrieve the epistemological coups of Pashukanism. If political economy can no longer sustain the extrusion of Karl Marx then jurisprudence can no longer justify the rustication of Evgeny Pashukanis. The imperative to defend the Pashukanist theory of the legal form is entrained in the socio-economic topology of our portentous times.

\section{Pashukanism and relative autonomism}

Analyses of law typically oscillate between two poles. On the one side there is instrumentalism, which repudiates the notion of legal autonomy, and which reduces law to an instrument of oppression and exploitation in the hands of the ruling class. On the other side there is formalism, which confers upon law complete autonomy from all class interests. Law, in this perspective, is comprehended as a supra-class institution governing the operation of such universals as right and justice. The fundamental choice, then, is between absolute legal subservience to the relations of production and absolute legal autonomy from them. ${ }^{15}$

Needless to say, Marxists have always rejected the formalism which would detach

Secondly, a general theory is an indivisible, coherent and cohesive construct and its defence therefore must be unconditional. Certainly, a general theory of law cannot be parcelled into good and bad bits. A general theory must be accepted or rejected in toto. It is a question (as the jazz classic teaches us) of all or nothing at all.

15 For general considerations of this opposition see, inter alia, Balbus "Commodity Form and Legal Form" 73-75, Collins Marxism and Law 61-74 and Tushnet "Is there a Marxist Theory of Law?" 178-182. 
legal relations from social relations. They have comprehended and opposed arguments for legal autonomy as nothing more than attempts by bourgeois ideologues to elevate law above the class inequities of capitalism and thereby to obfuscate precisely the class content of legal relations which Marxists seek to identify and make manifest. They have tended, in the main, to focus their critical efforts upon the comprehension of legal relations in terms of the base-superstructure problematic. For them the Marxist critique of law is about tracking the links between the constitution of the legal superstructure and the material interests of the contending classes which constitute society.

Marxists before Pashukanis tended to conceptualise law in instrumentalist and reductionist terms. They analysed law as a "mere" superstructural aspect of the social relations of production. For them the legal superstructure was a reflection, more or less direct, of the material interests of the dominant social classes. And law was a contrivance of class rule, a tool in the hands of the ruling class in its struggle against the ruled. In their efforts to render visible the class character of legal relations, they did not countenance the possibility of autonomy for the legal superstructure from its material base.

Latter-day radical jurisprudents, in response to the follies and tenacity of such instrumentalism-reductionism, have argued for the relative autonomy of law. This approach has highlighted the ways in which legal relations are not invariably direct reflections of ruling class interests, and how law, at times, may be harnessed to the cause of the dominated classes. It has included also an argument which endows law with a significant, sometimes even decisive, influence upon the constitution of the relations of production. In other words, the proponents of relative autonomy have sought to re-present the base-superstructure problematic in non-instrumentalist and anti-reductionist terms. ${ }^{16}$ This endeavour has led to more than one relative

\footnotetext{
16 They have been suspicious of or dissatisfied with Marx's own classification of law as a superstructural specificity and have invested considerable intellectual ingenuity into efforts to rescue legal relations from a "mere" superstructural existence. See, for example, Anderson, Passages from Antiquity to Feudalism 203-204, Balibar "The Basic Concepts of Historical Materialism" $233 \mathrm{ff}$ and Larrain A Reconstruction of Historical Materialism.
} 
autonomist declaring either that law itself is a relation of production or that it is constitutive of the relations of production! $!^{17}$

The argument for the relative autonomy of law, as described above, is a via media. It seeks to comprehend legal relations in terms which deny instrumentalism without promoting formalism. It is the classic position of compromise. ${ }^{18}$ And like most attempts at theoretical compromise, it fails to advance the materialist comprehension of the law. It is a position grown out of embarrassment at the excesses of the instrumentalism of mechanical materialism, but which quickly makes significant concessions to the objective idealism which constitutes the philosophical foundation of formalism. ${ }^{19}$ Relative autonomism is, in this connection, a retreat from Marxist materialism, which posits unequivocally that the superstructure indeed is determined in both the first and the final instance, as well as across the intervening continuum, by "the mode of production of material life". ${ }^{20}$

Pashukanis's project was to construct a general theory of law according to the precepts of Marxist materialism. In the pursuit of this goal, he was not concerned to examine the workings of legal relations as an aspect of ruling-class ideology. Nor was he interested especially in the impact which law, as a superstructural

17 See Fine Democracy and the Rule of Law 146, Hunt Explorations in Law and Society 207 and Collins Marxism and Law 89. Although not a relative autonomist himself, Binns 1980 Capital and Class 104 alleges, without an iota of serious argument, that Pashukanis understood law as "part of the base of society". In an exercise in straw-targeting, he goes on to suggest that "Pashukanis has produced a theory that, far from being based on Marx, is actually in sharp conflict with him". Miéville Between Equal Rights 88-90, too, in a somewhat strained and unconvincing submission, argues that Pashukanis himself accepted that the legal form was imbricated in the relations of production - a submission which mars an otherwise extremely valuable and very welcome defence of Pashukanism.

18 See Hunt Explorations in Law and Society 166: "Between the Scylla of autonomy and the Charybdis of determinism lies the haven of relative autonomy". Balbus "Commodity Form and Legal Form" 75 has a different view of the relative autonomy of law. For him, it is not a position of compromise between formalism and instrumentalism. Instead, it "purports to transcend the opposition between these positions by rejecting the common conceptual terrain on which they are based and elaborating a wholly different theoretical terrain". He goes on to construct a theory of law which is essentially Pashukanist. Unsurprisingly, Balbus's approach is not the conventional argument for relative autonomy.

19 The notion that law is an aspect of the relations of production is an idealist notion in that it entails an inversion of the basic materialist postulate of the relationship between superstructural relations and the relations of production.

20 Marx A Contribution to the Critique of Political Economy 20. 
phenomenon, may have upon its material base. ${ }^{21}$ For Pashukanis there is a fundamental problem with all analyses of law - instrumentalist, formalist or relative autonomist - which adhere to the base-superstructure problematic. None of these analyses is able to comprehend the form of law. They cannot explain why legal relations take the form they do. Analyses which are located within the parameters of the base-superstructure dichotomy are unable to distinguish consistently between law, on the one hand, and sociology and politics, on the other. Legal analysis is subsumed under social analysis, and the distinctiveness of the legal form is sacrificed in pursuit of the class content or otherwise of legal relations. Even the relative autonomist project to construct a more nuanced relationship between base and superstructure is unable to supersede the definitional bounds of this relationship and engage the form of law. Like its crasser variants, it has no need of a general theory of law. Its objectives are met easily and fully by a general theory of society.

Pashukanis identified the legal form itself as the analytical fulcrum of a Marxist general theory of law. ${ }^{22}$ His aspiration was to produce a Marxist theory of the legal form or, at least, to identify the elements of such a theory. In other words, he was concerned to theorise law as law, that is, as a superstructural specificity, and not as a mere ideological cloak for class relations of oppression and exploitation. It was a grand aspiration. And in Law and Marxism he succeeded, and grandly, in making the crucial theoretical breakthroughs required for the elaboration of a general theory of law.

21 Pashukanis had none of the concerns voiced by the new left about the place of law in the Marxist analytic. He adhered to the classical Marxist comprehension of law as an element of the superstructure. Indeed, Pashukanis Law and Marxism 39 defines his analytical terrain as the "legal superstructure as an objective phenomenon". However, he did not thereby assume an instrumentalist approach to law. Methodologically, he avoided the base-superstructure trap and insisted that the analysis of law must focus upon the legal form itself.

22 Because of his focus on the legal form, Pashukanis's general theory may be classified as formalist. However, his is a formalism which has nothing to do with the idealism which conceives of law as an autonomous form operating at some ethereal level without reference to things material. Pashukanis was concerned to analyse the legal form as a determined manifestation of the social relations of production and not as an independent phenomenon. In other words, his focus on the legal form is grounded in the material conditions constituting the content of the form. See further Miéville Between Equal Rights 79. 
Pashukanis ${ }^{23}$ was, of course, critical of those Marxist theories in which "the concept of law is examined exclusively from the point of view of its content". These, he complained, were nothing more than the bourgeois sociological theories of law into which the "element of class struggle" has been injected. ${ }^{24}$ They were not properly juridical, and whatever juridical concepts they did engage were treated as obfuscations which had to be decoded in order to uncover their class content. The concepts themselves did not merit any sustained theoretical attention. Pashukanis considered this approach to be fatal to the construction of a general theory of law. For him the Marxist analysis of law had to comprehend legal relations for themselves and not merely as the receptacle of class interests. This necessarily implied a focus upon law as form. In other words, the key to the construction of a Marxist theory of law lay in a "materialist interpretation of legal regulation as a specific historical form". ${ }^{25}$

Needless to say, Pashukanis accepted the traditional Marxist position that the legal form conceals a content which is structured by the inequities of the capital-labour relation. And he granted the importance of exposing the class or economic content of legal relations. But he was adamant that the proper object of Marxist jurisprudence had to be the legal form and its associated juridical concepts. Thus, he warns:

If, however, we forgo an analysis of the fundamental juridical concepts, all we get is a theory which explains the emergence of legal regulation from the material needs of society, and thus provides an explanation of the fact that legal norms conform to the material interests of particular social classes. Yet, legal regulation has still not been analysed as a form. ${ }^{26}$

Too many Marxists have surrendered to the impulse to dismiss the form of law as an obfuscation and, relying upon the analytical resources of Marxist political economy, they have sought to unveil the relations of domination and exploitation which constitute the content of the legal relation. Pashukanis departs radically from this

\footnotetext{
Pashukanis Law and Marxism 54.

Pashukanis Law and Marxism 53.

Pashukanis Law and Marxism 54.

Pashukanis Law and Marxism 55.
} 
conventional Marxist wisdom. He realised that the customary focus upon the content of the legal relation was the source of the poverty of Marxist legal theory. He perceived that the traditional Marxist aversion to the analysis of the legal form was the major obstacle to the construction of a general theory of law. Thus he set himself the task of elaborating such a theory on the basis of a materialist analysis of the legal form. The result was the so-called commodity form theory of law. ${ }^{27}$

\section{The fundamental tenets of Pashukanism}

Pashukanis's central thesis is disarmingly straightforward, namely that the historical origins of law as we understand it are to be found in the process of commodification. ${ }^{28}$ In other words, law is an attribute of the commodity economy, that is, the economy in which the raison d'être of production is exchange. The natural economy, in which production is for use by the producers, does not need law, for as long as the products of human labour remain primarily use values, custom is an adequate regulator of social relations. The appearance of the legal form on the historical stage is coterminous, more or less, with the transformation of the products of human labour into commodities. The world-historic transition from production for use to production for exchange is simultaneously the world-historic transition from custom to law. The genesis of the legal form thus is to be located in the genesis of the commodity form. Commodification spawns legality; the commodity form is the harbinger of the legal form. Pashukanis reminds us that it was Marx himself who brought to light "the deep interconnection between the legal form and the commodity form". ${ }^{29}$ Hence his methodological dictum:

\footnotetext{
$27 \quad$ The theory is referred to sometimes as the commodity exchange theory of law. The origin of this nomenclature is uncertain. See Fuller 1949 Michigan LR and Norrie 1982 International Journal of the Sociology of Law 431. Pashukanis himself did not name his theory. He was constructing a general theory of law. His Law and Marxism is exemplary of the theoretical advances and analytical sophistication achieved by the Bolsheviks under the leadership of Lenin and Trotsky. This is the process whereby the products of human labour are transformed from use values into commodities, that is, exchange values. Commodification begins in the pre-capitalist epoch but becomes generalised under capitalism, when labour-power itself is transformed into a commodity.

Pashukanis Law and Marxism 63.
} 
The critique of bourgeois jurisprudence from the standpoint of scientific socialism must follow the example of Marx's critique of bourgeois political economy. ${ }^{30}$

He considered Law and Marxism to be an extrapolation of the elements of the Marxist theory of law developed in Capital, Anti-Dühring and other Marxist classics. ${ }^{31}$

The relationship between law and the commodity is a necessary one. Since exchange is its logical conclusion, commodification entails the market. In other words, production for exchange requires the emergence of the conditions for exchange, that is, market relations. These must be or must at least appear to be human relations. Only human beings are capable of triggering the exchange process. Therefore the market in commodities necessarily must operate as one staffed and directed by human beings. Marx ${ }^{32}$ explains the matter in more detail thus:

It is plain that commodities cannot go to market and make exchanges of their own account. We must, therefore, have recourse to their guardians, who are also their owners ... In order that these objects may enter into relation with each other as commodities, their guardians must place themselves in relation to one another, as persons whose will resides in these objects, and must behave in such a way that each does not appropriate the commodity of the other, and part with his own, except by means of an act done by mutual consent. They must therefore recognise in each other the rights of private proprietors. This juridical relation ... is but the reflex of the real economic relation between the two. It is this economic relation that determines the subject-matter comprised in each such juridical act.

The market requires perfect equality not only amongst commodities but also amongst their owners.

Commodity equality is obviously necessary and is achieved in the calculation of

Pashukanis Law and Marxism 64.

Pashukanis Law and Marxism 38.

Marx Capital 88. 
exchange value in terms of the socially necessary labour time required to produce the commodities. The equality of commodity owners (who are naturally unequally endowed with talents, potentialities and the like) is necessary to ensure that the process is indeed one of exchange and not of appropriation or robbery. Marx ${ }^{33}$ again:

\begin{abstract}
Although individual $A$ feels a need for the commodity of individual $B$, he does not appropriate by force, nor vice versa, but rather they recognise one another reciprocally as proprietors, as persons whose will penetrates their commodities. Accordingly, the juridical moment of the Person enters here ... No one seizes hold of another's property by force. Each divests himself of his property voluntarily.
\end{abstract}

There can be no market in commodities unless each and every owner recognises and accepts each and every other owner as an equal. Owner equality is a necessary concomitant of commodity equality. Both are demanded by the market in commodities.

Owner equality is achieved legally. The aboriginal legal transaction is the invention of the legal subject. The transition from custom to law is exemplified in the concept of legal subjectivity. The legal subject is the disembodied commodity owner, disembodied, that is, of all natural advantage or disadvantage. According to Pashukanis: ${ }^{34}$

At the same time, therefore, that the product of labour becomes a commodity and a bearer of value, man acquires the capacity to be a legal subject and a bearer of rights.

In other words, commodification and juridification are parallel historical processes. The commodity owner enters and participates in the market as a legal subject, perfectly equal, in terms of rights and duties, to every other commodity owner.

It is the rise of the notion of legal subjectivity which abolishes the natural inequality of

\begin{tabular}{ll}
\hline 33 & Marx Grundrisse 243. \\
34 & Pashukanis Law and Marxism 112.
\end{tabular} 
people. ${ }^{35}$ Every legal subject is deemed to be exactly equal to every other legal subject. Such equality, as intimated above, is a necessary attribute of the market. It is the guarantor of the exchange relation and hence of the reproduction of the commodity economy. It, in its turn, is guaranteed by the state, which possesses the capacity to enforce the law. As Harvey ${ }^{36}$ notes, the juridical moment:

supposes not only a solid legal foundation to exchange but also the power to sustain private property rights and enforce contracts. This power, of course, resides in "the state". The state in some form or another is a necessary precondition to the establishment of values.

Pashukanis $^{37}$ similarly discerns a definite historical interrelation between the development of the commodity economy and the development of "bourgeois statedom", which, he tells us:

can be traced to a single principle, according to which neither of two people exchanging in the market can regulate the exchange relation unilaterally; rather this requires a third party who personifies the reciprocal guarantees which the owners of commodities mutually agree to as proprietors, and hence promulgates the regulations governing transactions between commodity owners.

The legal subject who asserts or attempts to assert himself as superior to his fellows and not to respect their right to equality usually has to answer (or be made to appear to answer) for his opportunism to the law enforcement agencies of the state.

Law, thus, is the ethos of the market generalised to human relations. The idea that we are all equal before the law, regardless of our de facto natural and socioeconomic differences, has its origins in the equality which forms the bedrock of all

35 Formally, it also abolishes social inequality. Of course, in practice the legal subjectivity of a peasant or proletarian is seldom of consequence against the social power of the ruling elite. For, as Pashukanis Law and Marxism 127 reminds us, "the capacity to be a legal subject is a purely formal capacity".

36 Harvey The Limits to Capital 18-19.

37 See Pashukanis Law and Marxism 148-150. The class nature of the capitalist state is never far from his mind. Thus he adds almost immediately that "the bourgeoisie has never, in favour of purity of theory, lost sight of the fact that class society is not only a market where autonomous owners of commodities meet, but is at the same time the battlefield of a bitter class war, where the machinery of state represents a very powerful weapon". 
market relations. The idea that we all have certain inalienable rights which are enforceable against all comers is derived historically from the rights of the commodity owner. The commodity economy is the fons et origo of the concept of legal equality. It is the logic of this economy which produces the legal relation. Pashukanis ${ }^{38}$ puts it thus:

The legal relation between subjects is simply the reverse side of the relation between products of labour which have become commodities.

The birth of law is structured by the world-historic transition from the natural to the commodity economy. Our notion of equality is a fundamentally legal one, and it derives from our transformation into legal subjects. We had to acquire legal subjectivity, and hence legal equality, in order to become successful commodity owners, that is, in order to warrantee the integrity of the market. The juridical worldview rests upon the idea of equality. Concepts and interactions which do not embrace equality have to be comprehended as non-juridical. Exchange is the fundamental juridical relation. It is the hallmark of the commodity economy. And it is the source of the transformation of every natural person into a juridical person. ${ }^{39}$

Such are the essentialia of the general theory of law constructed by Pashukanis. It is a theory which, despite the objections of detractors, is founded surely and consistently upon the precepts of classical Marxism. Pashukanis undertook to do what Marx himself had never had the opportunity to do, namely, produce a Marxist general theory of law. He made use of the episodic remarks on the critique of the legal relation left by Marx and Engels to fashion a Marxist theory of law that is derived directly from the Marxist theory of value. Law and Marxism is to the critique of legal relations what Capital is to the critique of economic relations.

The crucial elements of Pashukanis's theory may be summarised in the following five propositions:

Pashukanis Law and Marxism 85.

39 Marx Grundrisse 246. See also Harvey The Limits to Capital 18-19. 
1. The subject-matter of a general theory of law is the legal form, that is, the legal superstructure constituted in terms of the fundamental juridical concept of legal subjectivity. ${ }^{40}$ The emergence of the legal subject expresses the world-historic transformation of human relations into legal relations. ${ }^{41}$

2. The genesis of the legal form, and hence of the legal subject, is to be found in the relations of exchange which accompanied the rise of commodity production. ${ }^{42}$ The natural economy is a pre-juridical era of human social evolution. The juridical era commences with petty commodity production and summates in generalised commodity production, that is, capitalism.

3. The legal form is the homologue of the commodity form. The legal subject is the cell-form of legal relations in the same way as the commodity is the cell-form of economic relations. ${ }^{43}$ The analysis of the legal form must proceed, therefore, from the analysis of the commodity form. ${ }^{44}$

4. The legal subject is a commodity owner and vice versa. They coalesce in the process of exchange. The circulation of commodities could not occur without every commodity owner becoming also a legal subject, for it is only as a legal subject that the commodity owner could make his products available for exchange in the market. In other words, the birth and development of commodity exchange entailed the birth and development of the legal subject. ${ }^{45}$

5. The phenomenon of law, then, arises in tandem with the economic category of value. ${ }^{46}$ Legal relations are, in this connection, the form in which exchange relations materialise. The legal subject is the quotidian purveyor of the spirit of the commodity. The core legal principle of equality is the law of value

\footnotetext{
Pashukanis Law and Marxism 47.

Pashukanis Law and Marxism 40.

Pashukanis Law and Marxism 43.

Pashukanis Law and Marxism 111-113.

Pashukanis Law and Marxism 111.

Pashukanis Law and Marxism 112-113.

Pashukanis Law and Marxism 117.
} 
juridified. ${ }^{47}$ Therefore the general theory of law must be concerned, first and foremost, with mapping the interconnections between the legal form and the commodity form.

As intimated earlier, the theory of law developed by Pashukanis has every claim to be regarded as the Marxist theory of law. It was Marx and Engels who developed the materialist conception of history upon which Pashukanis's theory is based so meticulously. It was Marx and Engels who made the analytical distinction between base and superstructure which led Pashukanis to the conclusion that the form of law should be the object of the Marxist theory of law. It was Engels who taught us that the bourgeois world outlook is fundamentally a juridical one. It was Marx who showed us that legal subjectivity and its accompanying ethos of equality are necessary properties of the market in commodities. ${ }^{48}$ Pashukanis himself was clear about the aetiology of his work. Thus, he tells us:

In Marx, the analysis of the form of the subject follows directly from the analysis of the commodity form. ${ }^{49}$

He knew that he was simply developing and synthesising the real discoveries made by Marx and Engels. He was able to elaborate the so-called commodity form theory of law only because Marx and Engels had long ago provided all the signposts required for such an elaboration. ${ }^{50}$

\footnotetext{
Pashukanis Law and Marxism 38.

Pashukanis Law and Marxism 111.

Pashukanis Law and Marxism 111.
}

Löwy The Politics of Combined and Uneven Development 8 says of the scattered comments by Marx and Engels on the theory of permanent revolution that "it is not possible to speak of a coherent and systematic theory of permanent revolution in Marx and Engels. Rather, there is a series of fragmentary conceptions, prophetic intuitions and inchoate perspectives, which intermittently appear and reappear but are never ordered in a rigorous doctrine or global strategy. Their importance is above all methodological". Virtually the same may be said of Marx and Engels on the general theory of law. And in the same way as it was left to Trotsky to fashion their remarks into the theory of permanent revolution, so it was given to Pashukanis to produce the general theory of law. 


\section{The poverty of anti-Pashukanism}

Despite his rather weighty Marxist credentials, criticism of Pashukanis has been widespread, not least amongst analysts who would consider themselves Marxist. There are six objections to the general theory of law which stand out for being repeated by various critics. They are, firstly, that the theory is too formal and hence too abstract; secondly, that premising the existence and operation of the legal form upon the evolution of the commodity form is an unMarxist exercise in economic reductionism; thirdly, that it is methodologically incorrect to theorise law in terms of the relations of commodity exchange (instead of commodity production); fourthly, that the theory incorrectly comprehends law as a specifically capitalist phenomenon; fifthly, that the supposedly general theory of law which Pashuskanis claims to have fashioned, in truth, is not general at all; and lastly, that the theory encouraged a form of legal anarchism which provided a favourable milieu for the rise of Stalinism.

The remainder of this essay will confront all of these six objections in some detail, with a view to demonstrating that each is of no critical consequence whatsoever to the integrity of the Pashukanist general theory of law.

\subsection{Abstractness or abstraction?}

The first charge was levelled against Law and Marxism as early as 1930 by Korsch, ${ }^{51}$ who complained of the "extraordinarily abstract nature of this work" which, he adds, "in parts intensifies to become downright scholasticism". Fine ${ }^{52}$ concludes that "the real problem ... in Pashukanis's intervention lay in its abstractness". And Young ${ }^{53}$ has adjudged that his "emphasis upon the form of law and punishment produces ... a strangely abstract explanation". The alleged divorce between Pashukanis's theory and reality has prompted Hirst ${ }^{54}$ to label his concept of law

\footnotetext{
Korsch "Appendix" 193-194.

Fine Democracy and the Rule of Law 163.

Young "Punishment and Social Organisation" 116.

Hirst On Law and Ideology 111.
} 
idealist, Warrington ${ }^{55}$ to liken his theoretical propositions to "wild flights of fancy", and Hunt ${ }^{56}$ to allege the correspondence between the commodity form and punishment to be "nothing more than the verbal equation achieved by the dual usage of equivalence and the assertion that the verbal correspondence evidences a real correspondence". Even the sympathetic Sayer, ${ }^{57}$ who credits Pashukanis with developing "with considerable brilliance" Marx's insights into the legal form, feels constrained to refer to his "at times, undue abstractness". And Head's ${ }^{58}$ recent critical reappraisal of Pashukanis evaluates the general theory to be "quite abstract in its approach".

The charge of abstractness is, at bottom, a claim that the general theory is unable to comprehend the concrete life of the legal form and, hence, that it is out of touch with the real world of legal relations. It is submitted that, despite its popularity across the gamut of critiques of Pashukanis, the accusation of abstractness against him is misplaced. It derives from a shared misunderstanding amongst the critics of the role of abstraction in the Marxist method. ${ }^{59}$ Marx ${ }^{60}$ taught us that:

In the analysis of economic forms ... neither microscopes nor chemical reagents are of use. The force of abstraction must replace both.

This same has to be true also of the analysis of the legal form. The only instrument available for the construction of a general theory of law is the force of abstraction. The process of abstraction is crucially about the separation of the essential from the non-essential. Hegel, ${ }^{61}$ from whom Marx learned the dialectic, understood that scientific comprehension requires that "the essential be distinguished and brought into relief in contrast with the so-called non-essential". The analyst must be able to

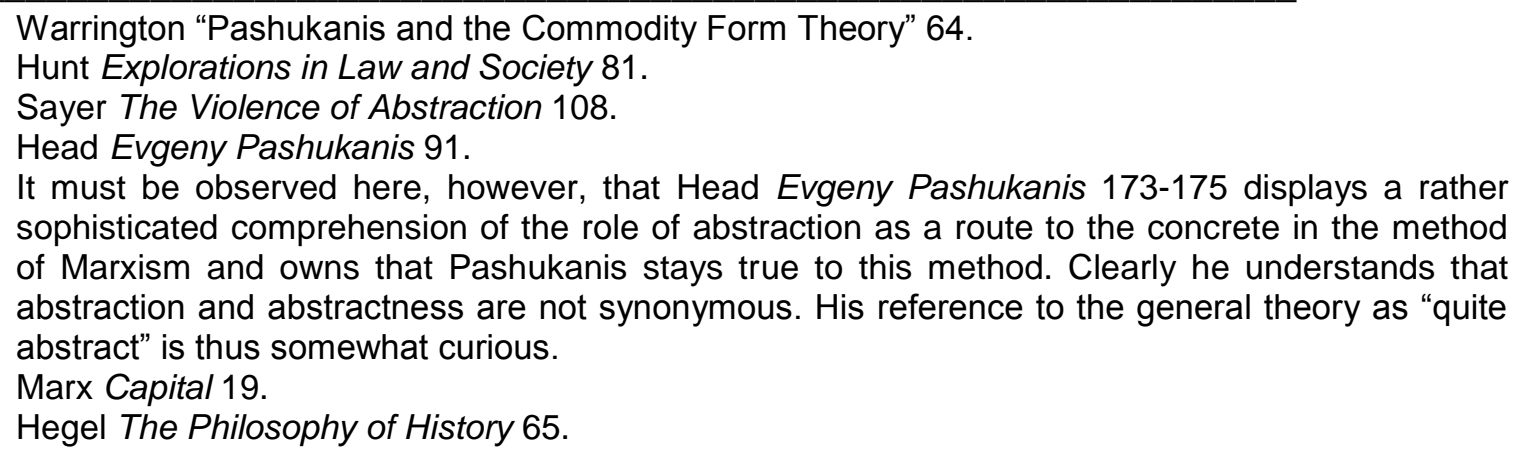
sophisticated comprehension of the role of abstraction as a route to the concrete in the method of Marxism and owns that Pashukanis stays true to this method. Clearly he understands that abstraction and abstractness are not synonymous. His reference to the general theory as "quite abstract" is thus somewhat curious. 
get to the heart of the matter, so to speak. And, in analytical terms, the heart is to be found, not in the body, but in the cells comprising that body. ${ }^{62}$ In other words, the analysis of a social form such as law must be located at the cellular level. This level cannot be reached other than by a process of systematic abstraction from those properties of the form which constitute it above the cellular level.

Marx ${ }^{63}$ perceived the commodity to be "the economic cell-form" of the capitalist mode of production and devoted the bulk of the first volume of Capital to its analysis, at the expense of such "non-cellular" economic aspects as price, profit, rent, business cycles, crises, and the like. A general theory of law must, similarly, discard all that is secondary and include in its ambit only those relations which are constitutive of the legal form. Pashukanis understood this. Not only does he refer expressly to Marx's statement cited above, but he extends it to the analysis of the legal form:

The theory of law makes use of abstractions which are no less "artificial" [than those used by Marx in the analysis of economic forms]: the research methods of natural science cannot discover a "legal relation", or a "legal subject" either, yet behind these abstractions too lie perfectly real social forces. ${ }^{64}$

Such abstractions are the analytical gateway to comprehension of the concrete. "They constitute the building blocks of any analysis of the real world, because of, rather than despite, their abstraction". ${ }^{65}$ Pashukanis knew that in order for him to generate a general theory of law he had to isolate the fundamental juridical concepts from the myriad of legal rules and regulations. He understood that a general theory of law had to comprehend the purified legal form, unencumbered by the diversions of "law in practice" or "law in society". 66

The general theory of law constructed by Pashukanis is abstract only in the sense




that, in terms of the Marxist method, it is located at a high level of abstraction. The neo-Marxist critics who censure such abstraction do not appear to comprehend this most basic of Marxist methodological tenets. They misunderstand both the purpose and process of abstraction. They confuse the identification for analysis of an unadulterated aspect of social reality with an alleged escape from that reality. Sweezy ${ }^{67}$ sets the record straight in this regard:

The legitimate purpose of abstraction in social science is never to get away from the real world but rather to isolate certain aspects of the real world for intensive investigation. When, therefore, we say that we are operating on a high level of abstraction we mean we are dealing with a relatively small number of aspects of reality; we emphatically do not mean that those aspects with which we are dealing are not capable of historical investigation and factual illustration.

Pashukanis's general theory of law operates at a high level of abstraction. In order to analyse the law, he had to engage with the legal form as a pristine insularity. He had to make a number of simplifying assumptions which reduced the legal relation to its "purest form" and "free of all unrelated disturbances". ${ }^{6}$

This meant downplaying the social aspects of law and de-emphasising its class content in favour of an analytical focus upon "the development of the most fundamental and abstract juridical concepts, such as 'legal norm', 'legal relations', 'legal subject' and so on". ${ }^{69}$ These are the abstractions which Pashukanis required for the construction of his general theory of law. They are the abstractions with which he was able to separate the essential from the non-essential, and to subject the essential relations of the legal form to the rigorous analysis from which the general theory could emerge. As a general theory it is necessarily situated at a high level of abstraction. But it is by no means an abstract theory, in the sense that it is divorced from the real world of the legal form. ${ }^{70}$ In point of fact, it is the only theory of law

\footnotetext{
S7 Sweezy The Theory of Capitalist Development 18.

68 Sweezy The Theory of Capitalist Development 17 \& 20.

69 Pashukanis Law and Marxism 47. When he refers to these juridical concepts as fundamental and abstract, he is identifying them as the concepts which have been singled out, using the force of abstraction, as those which will provide insight into the purified legal form.

70

See Miéville Between Equal Rights 79 who makes the point that "the legal form which interested
} 
which has been able to provide a scientific link between the legal form and the capital relation, and which thereby comes closest to comprehending that world, in historical materialist terms, for the bourgeois world that it really is.

Of the fundamental juridical concepts which he identifies, Pashukanis places the legal subject at the heart of his theory, as emblematic of the legal form. Comprehension of law requires comprehension of the legal subject as the prime component of the legal relation. For Pashukanis there is a structural coincidence between the commodity as the elemental economic unit and the subject as the elemental legal unit. In a capitalist economy, every person is transformed into a legal subject exactly equal to every person. Legal subjectivity is the great leveller amongst people in the same way as labour time is the great leveller amongst commodities. The legal subject and the commodity, in this regard, are linked umbilically. However, too many critics understand this connection as a purely logical one made by Pashukanis in a flash of brilliance. ${ }^{71}$ Hence the oft-heard allegation of abstractness.

However, the transformation of the person into the legal subject is not simply the logical analogue of commodity exchange. The commodity form and the legal form are not mere ratiocinatory counterparts. The transformation of the person into a legal subject was historically determined by the transition from the natural to the commodity economy. Pashukanis ${ }^{72}$ is unambiguous on this matter:

Like the majority of jurists, Dernburg tends to treat the legal subject as "personality in general", that is to say, as an eternal category beyond particular historical conditions. From this point of view, being a legal subject is a quality inherent in man as an animate being graced with a rational will.

He continues:

Pashukanis was one derived from actually-existing law, rather than from some abstract notion of law".

71 See, for example, Stone 1985 Law and Society Review 43) and Warrington "Pashukanis and the Commodity Form Theory" 48.

72 Pashukanis Law and Marxism 117. 
Historically, however, it was precisely the exchange transaction which generated the idea of the subject as the bearer of every imaginable legal claim. Only in commodity production does the abstract legal form see the light. $^{73}$

In other words, the homology between the commodity and the legal forms is given historically by the development of capitalist relations of production. The capacity to become a legal subject is inscribed in the evolution of human society into a society of generalised commodity production. The history of the development of law is the history of the development of the legal subject. Marx and Engels recognised this fact long before Pashukanis did. When, therefore, Pashukanis bases his general theory of law upon the legal subject he is systematising what Marx and Engels had the opportunity to state only episodically. Again, Pashukanis's systematisation of Marx and Engels necessarily entailed reliance upon the force of abstraction. However, the result was not an abstract general theory of law. It was a theory which captured perfectly the real historical nexus between the legal subject and the commodity.

The allegation of abstractness, therefore, does not withstand scrutiny and must be rejected. Pashukanis sought to theorise law as form, and to do so from a historical materialist perspective. The use of the force of abstraction led him to identify a number of juridical concepts as fundamental, with the concept of the legal subject being primary amongst these. His interrogation of this concept led him to uncover a correspondence between the legal subject and the commodity, Marx's fundamental economic abstraction. Despite the fact that it operates at a high level of abstraction, the relationship between the commodity form and the legal form is a very real one. The legal form is derived directly from the commodity form. This relationship is not apparent at a lower level of abstraction, such as the class content of the law. It becomes evident only at the high level on which Pashukanis's theory operates.

Every property of the legal relation which does not contribute to the comprehension of the legal cell-form must be regarded as non-essential and, therefore, must be excluded from the elements of a general theory of law. This is what Pashukanis did.

73 Pashukanis Law and Marxism 118. See also Arthur "Editor's Introduction" 14. 
And thereby he was able to achieve the analytical coup which illuminated the real genesis of the legal form and which formed the basis of his elaboration of the general theory of law. Those who decry the theory as being too abstract or too formal or too fanciful appear not to appreciate the role of the force of abstraction in the construction of theoretical paradigms. They appear, also, to be requiring that, in order to avoid the charge of abstractness, the elaboration of a theory be an activity informed by the articles of empiricism and the methods of positivism. Such a requirement, of course, violates every epistemological postulate of Marxism and cannot be taken seriously as a supposed deficiency of Pashukanis's general theory.

It is not possible to construct a theory of any aspect of social reality without resorting to abstraction. Every theorist, whether Marxist or not, must rely upon the force of abstraction to make sense of the relation being analysed. We never are able to comprehend any social phenomenon in its full complexity, and necessarily must dismantle it in order to be able to think about it in a way which will allow us conceptually to approximate its reality. If we do not do so, that is, if we do not separate essential from non-essential factors by abstraction and focus our analytical attention upon the essentials, the relation which we seek to comprehend forever will remain beyond our ken. Abstraction is, in a word, a universal theoretical injunction. ${ }^{74}$ Pashukanis understood this and produced a theory of law which, because it is a general theory, necessarily is located at a high level of abstraction. It is his reliance upon the force of abstraction which explains the alleged abstractness of the general theory.

Critics who expect him to be less abstract are, in reality, demanding that the theory operate at a significantly lower level of abstraction. They forget, of course, that a general theory requires law to be abstracted at the level of generality firstly and primarily of the capitalist mode of production; and thereafter the abstractions of class society and of human society have to be given their epistemological due. ${ }^{75}$ Features

\footnotetext{
See Ollman Dialectical Investigations 24-27.

Ollman Dialectical Investigations 55-58 identifies seven levels of generality in the process of
} abstraction. Marx's abstractions are primarily at level 3 , focusing on the peculiarities of capitalist 
such as specific laws or even the law of a given social formation in the capitalist epoch need to be shifted out of focus in order to bring into focus the anatomy of the legal form itself. In other words, the key to the comprehension of the legal form is to be found outside the operations of the legal system; rather, it is to be found in the relationship between the fundamental juridical concepts and the fundamental concepts of political economy. The charge of abstractness is, in this context, a nonsense.

It is also disingenuous. It is the kind of charge which the accused never can rebut, for the criterion of abstractness is always a subjective one chosen by the accuser. And it is the accuser who decides, ultimately, whether or not any attempt by the accused at concretisation has been successful. ${ }^{76}$ It is the classic fall-back allegation, made by the critic who has had little or no success in his efforts to invalidate the core propositions of his object of criticism. ${ }^{77}$ Such a critic usually has been bested theoretically and attempts to avoid capitulation with the cynical charge of abstractness. ${ }^{78}$ Disingenuous allegations deserve only to be dismissed for the fabrications that they are. Certainly, the charge of abstractness is of no moment in relation to Pashukanis's general theory of law.

\subsection{Economism or materialism?}

Pashukanis is regularly charged with economism. A number of his critics allege that his general theory is the product of an economic reductionism purporting to explain legal relations as epiphenomena of the economic base. The charge of economism

society. Class and human society are level 4 and level 5 abstractions respectively. Level 1 and level 2 concern the individual, while level 6 and level 7 deal with the animal and natural worlds.

76 The charge of abstractness also takes no account of the difference between the mode of investigation and the mode of exposition in theoretical work. The former is usually an intensely empirical and intensively concrete exercise upon which the latter is based. The allegation that theory is abstract cannot be sustained on the strength of the apparent features of the mode of exposition.

77 See Sparkes Talking Philosophy 17.

78 It is a charge of the same order as labelling a troublesome opponent fascist or communist or bourgeois or sexist or racist because one cannot sustain a substantive argument against that opponent. 
was made by Stuchka ${ }^{79}$ as early as 1927 when he attacked Pashukanis's theory for "its one-sidedness insofar as it reduced all law to only the market, to only exchange as the instrumentalisation of the relations of commodity producers". Subsequently Kelsen ${ }^{80}$ has accused Pashukanis of "reducing, in the field of jurisprudence, legal phenomena to economic phenomena". Collins ${ }^{81}$ has concluded that Pashukanis subscribed to an economism which resulted in his producing a "crude materialist explanation of the content of law". Davis, ${ }^{82}$ too, has registered a strong objection to the alleged "economism of Pashukanis" and Sumner ${ }^{83}$ has adjudged Pashukanis's work to be "a classic example of economism in Marxist theory of law".

It is submitted that there is nothing economistic about Pashukanis's general theory. He did not reduce the juridical to the economic, nor did he seek to derive legal changes directly or exclusively from economic changes. His concern was to produce a Marxist theory of law. His theoretical endeavours were informed, of course, by the materialism of classical Marxism. Now it may be owned readily that Marxist materialism is unequivocally deterministic. But it is a determinism which is informed by and derived from the recognition of the impact of being upon consciousness. It is an axiom of Marxism that being is constituted materialistically in the social relations of production. Marxist determinism is thus simply an acknowledgement of the priority, in nature and social life, of matter over mind. In this connection it must be acknowledged that Marxism does teach us that reality has an objective existence independent of what we may think of it. And it does hold that historical development and social existence, like death, are rational processes which are governed by material necessity, regardless of our distaste for them. For Marxism, determinism means the unconditional acceptance of "the decisive primacy of the socio-economic level over juridical, political and cultural phenomena". ${ }^{84}$

However, it must be stressed that Marxist determinism is not by any means an

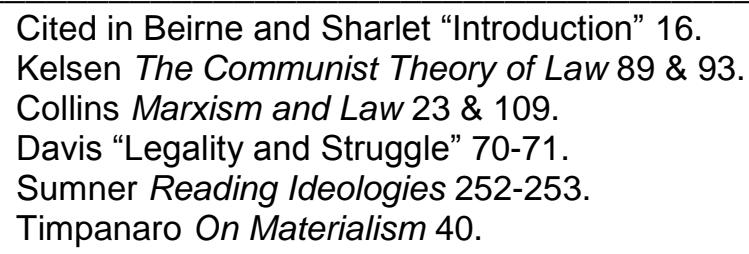


economic determinism. In other words, the determinism of Marxism does not reduce social actors to hapless victims of structural economic processes over which they have no control. It is instead a determinism which endows social actors with a vital say in the constitution of society. In this regard it is a determinism which is, firstly, materialist in that it bases itself, as Engels ${ }^{85}$ tells us, upon Marx's discovery of "the law of development of human history", namely:

the simple fact, hitherto concealed by an overgrowth of ideology, that mankind must first of all eat, drink, have shelter and clothing, before it can pursue politics, science, art, religion, etc.

Secondly, it is a determinism which is dialectical, giving full recognition to the effectivity of the non-material. It does not debase the non-economic dimensions of human existence, including law, to absolute dependence upon or total subservience to the so-called economic factor. Despite the allegations of its detractors, the determinism espoused by Marxism is a determinism which celebrates agency.

If the determinism of Marxism has to be labelled at all, perhaps it may be described usefully as a socio-economic determinism, as opposed to an economic determinism. Mande ${ }^{86}$ puts it thus:

Historical materialism in no way affirms that material production ("the economic factor") directly and immediately determines the content and form of all so-called superstructural activities. Moreover, the social base is not simply productive activity as such, and even less is it "material production" taken in isolation. It is the social relations that people form in the production of their material life. In fact, historical materialism is not, therefore, economic determinism, but socio-economic determinism.

The point is that Marxist materialism and economic determinism are incompatibles. The latter asserts a direct determination of the superstructure by the base and lapses easily into the compartmentalisation of dualism. The former is committed to the monist conception of the world and postulates a dialectical relationship between

\footnotetext{
$85 \quad$ Engels "Speech" 681.

86 Mandel Introduction to Marxism 175, original emphasis.
} 
base and superstructure. It ought to be evident that Marxist determinism and economic determinism occupy distinct and contrary epistemological terrains. Certainly, Marxism neither shares nor condones any of the crudenesses of economic determinism. Instead, it is committed to the nuanced analytic of socio-economic determinism.

Pashukanism forms part of the tradition of classical Marxism and has nothing whatsoever in common with any crude materialism which engenders economic reductionism. The general theory of law is an exemplar of socio-economic determinism in terms of which the genesis of the legal form is conditioned by the social relations of production, which spawned the commodity form. It accepts that law is determined by socio-economic circumstances in the Plekhanovite sense that "law cannot rise higher than the socio-economic order". ${ }^{87}$ It does not accept that law and legal development are always and necessarily direct reflections of economic relations. Indeed, as Plekhanov ${ }^{88}$ demonstrates, economic determinism patently has no material foundation and in the end turns out to be "nothing but a variety of idealism". In this regard, the denigration of Pashukanism as economism demonstrates nothing more than a profound perplexity about the meaning of Marxist materialism on the part of the maligner.

What is more, the charge of economism betrays a crucial misunderstanding of Pashukanis's method. He was not interested in theorising the content of law or of comprehending legal relations in terms of the class struggle. Indeed, for him it was precisely these concerns which, till then, had diverted the development of the Marxist theory of law away from a necessary and proper focus upon the legal form. Such a focus, Pashukanis understood, would have to be located at a level of abstraction high enough to bring into unadulterated relief the relation between the economic and legal cell-forms. To be sure, there is a one-sidedness here, but only in the sense of a methodological imperative required to lay bare the materialist sources of the legal form. Certainly, that is not the same as positing a relation of slavish operational

See Head Evgeny Pashukanis 41.

88 Plekhanov The Materialist Conception of History 8. 
dependence of law upon the economy. Pashukanis did not reduce law to the market. Instead, he extrapolated into a general theory of law Marx's and Engels's discovery that the legal form has its genesis in the market.

The speciousness of the charge of economism is acknowledged even by Fine ${ }^{89}$ one of Pashukanis's more vocal critics, in the following extract:

Pashukanis traced the logic of the connection between commodity exchange and legal regulation, and on this basis argued for the twofold nature of the transition to communism: it was to be both an economic process involving the replacement of market relations by planned production and distribution, and a juridic process involving the replacement of legal regulation by what Pashukanis called "technical" forms of regulation. In this respect the charge that Pashukanis was "economistic" is not strong, since he conceived of the transition as comprising not only a transformation of economic relations but also a self-conscious and planned transformation of authority relations.

The charge of economism is one which, in the final analysis, turns upon an alleged liquidation of agency in things juridical. However, it must yield to the fact that Pashukanis's general theory of law makes a virtue of agency.

\subsection{Exchange or production?}

The third recurrent criticism of Pashukanis is that, contrary to the Marxist method, he derived his general theory of law from exchange. It is an argument which is compressed in the idea that Pashukanis's is a commodity exchange theory of law. The critical consensus appears to be that, in order to qualify as Marxist, the theory of law must be rooted in production, not exchange. Despite differences in detail, most left critics posit that the Marxist theory of law should be informed by the relations of commodity production and not, as Pashukanis believes, the relations of commodity circulation. For them, law as a superstructural effectivity has to be theorised in terms of its relationship to the process of commodity production. They claim that this was Marx's method and ought to have been Pashukanis's. His detractors are not

89 Fine Democracy and the Rule of Law 163. 
reluctant to condemn him as unMarxist for this alleged deviation from the received canons of Marxism.

Again, one of the earliest assaults along these lines came from $\mathrm{Korsch}^{90}$ who, in his 1930 review of Law and Marxism, highlighted what he understood to be the "extremely strange - for a 'Marxist' - overestimation of 'circulation'" by Pashukanis. Young's ${ }^{91}$ suggestion that Pashukanis's approach entails a "deviation from the commonly accepted notions of the relationship between law and economy" falls squarely within the purview of this line of criticism. Lloyd \& Freeman ${ }^{92}$ join the chorus of critics with the allegation that "Pashukanis's theory concentrates on the exchange of commodities, as if this were all capitalism was about". Warrington ${ }^{93}$ identifies the "dominance of exchange" as one of his objections to Pashukanis, and submits that he "appears to have written production out of the law". He continues:

Pashukanis has failed to make the logical allowances necessary for the importance of the production process itself in the development of a social system. Legal theories which attempt to base themselves on "social reality", as Pashukanis claimed, must incorporate the production process into their legal analysis or make sufficient allowances for its importance in relation to the legal system as a whole. Pashukanis's theory is based on a society of commodity production, yet almost eliminates the process of production from history. ${ }^{9}$

The idea that this concern with exchange constitutes an unMarxist deviation is pressed home by Fine,${ }^{95}$ who tells us that:

Whereas Marx derived law from relations of commodity production, Pashukanis derived it from commodity exchange. This was the essence of their difference.

He concludes that Pashukanis in effect aligned himself with the methods of

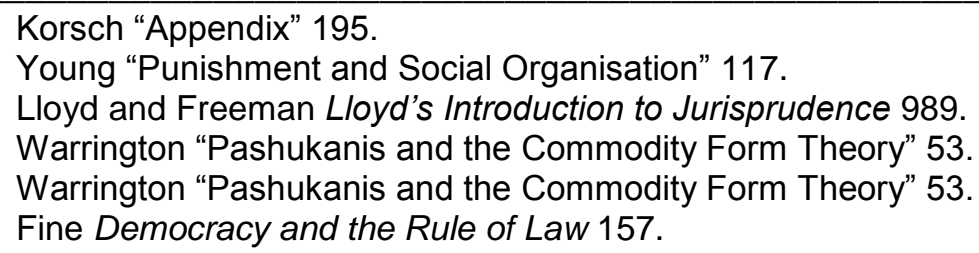


bourgeois jurisprudence when he abstracted exchange from the relations of production. The result was an approach to law which had "an entirely different coloration from that of Marx's". ${ }^{96}$ Collins ${ }^{97}$ opines that:

Pashukanis indulged in all the vices of reductionism, that is, he purported to explain all legal rules as reflections of commodity exchange.

Stone ${ }^{98}$ concurs with this assessment, and accuses Pashukanis of being "crudely reductionist".

Generally, the critics agree that Pashukanis has misread Marx on the question of exchange and production relations ${ }^{99}$ and that his focus upon exchange is an index of considerable theoretical confusion. ${ }^{100}$ The argument has been potent enough to prompt even Norrie, ${ }^{101}$ who is a staunch supporter of Pashukanis against the criticisms of Warrington especially, to express a measure of concern about the apparent dominance of exchange:

It must be conceded that Pashukanis does concentrate on the relationship between exchange and law in the General Theory.

Head, ${ }^{102}$ too, acknowledges that Warrington "made a valid point" when he

$96 \quad$ Fine Democracy and the Rule of Law 159.

97 Collins Marxism and Law 109.

98 Stone 1985 Law and Society Review 45.

99 See Warrington "Pashukanis and the Commodity Form Theory" 57-58.

100 See Fine Democracy and the Rule of Law 158.

101 Norrie 1982 International Journal of the Sociology of Law 426.

102 Head Evgeny Pashukanis 215-218. He goes on to suggest that the "real problem" with Pashukanis is the failure of the general theory to relate law to the "extraction of surplus value in the production process". He contends that "the only source of surplus value in the economy as a whole is the labour power of the working class, which is consumed in production". For him, Pashukanis's privileging of exchange leads him away from appreciating the "essential role of law" in the capitalist imperative to exploit proletarian labour power as the well-spring of surplus value. However, Pashukanis was not analysing capitalist law. It is true that he argued that the legal form proper is an attribute of the capitalist mode of production (see section 4.4 below). But that was a conclusion emerging from his investigations into law as a genus and not into law as a capitalist phenomenon. The point is that surplus value is a category of the political economy of capitalism and, although it is derived from the exploitation of labour-power as a commodity, it forms no necessary aspect of the general theory of law. Its omission does not constitute an analytical lacuna. The commodity in general is a sufficient analytical fulcrum for the general theory. Its validity does not depend upon foregrounding or even incorporating the unique commodity, 
"contended that Pashukanis wrote production out of the law, whereas capitalism is a process of production, and exchange is merely part of that process". It is submitted that this kind of concession is quite unnecessary and gives the criticism a credence which it does not deserve. For, as will be shown below, the claims that Pashukanis misunderstands Marx and is theoretically confused are petty, and prove only that the critics misunderstand both Marx and Pashukanis.

Marx ${ }^{103}$ taught us (in the famous Preface to $A$ Contribution to the Critique of Political Economy) that property relations are the legal expression of the relations of production. In other words, he held that there was an especially close relationship between the economic base and the legal superstructure. ${ }^{104}$ However, Marx did not hold that law is to be (or even can be) derived directly from the process of production. He did not say that the genesis of the legal form is to be found in the production of commodities, as Pashukanis's critics apparently would have us believe. He spoke, in the Preface, of the totality of the social relations of production constituting the economic base upon which arises the superstructure. ${ }^{105}$ As a superstructural effectivity, law obviously is to be derived from the relations of production. But the relations of production are not coterminous with the process of production. Nowhere does Marx even hint at such an equivalence. In other words, nowhere is there any suggestion that the legal form is an expression of or arises from the process of production. The totality of the relations of production obviously and necessarily encompasses the process of production, but it also incorporates the process of circulation or exchange, just as obviously and necessarily. In the capitalist

103 labour-power, as the source of surplus value.

103 See Marx K A Contribution to the Critique of Political Economy 21: "At a certain stage of development, the material productive forces of society come into conflict with the existing relations of production or - this merely expresses the same thing in legal terms - with the property relations within the framework of which they have operated hitherto". This one sentence is the source of the so-called "problem of legality" in terms of which Marx allegedly equated relations of production and property relations, and since property relations are legal relations, there can be no real ontological difference between base and superstructure. However, the "problem of legality" is a spurious one since the culprit sentence does not in fact equate production relations with property relations. Marx's purpose in delineating property relations as the legal expression of production relations is precisely, as Plamenatz Man and Society 281 observes, to exclude law from the base, and "to suggest that relations of production can be defined without bringing the notion of law into the definition".

104 See Jakubowski Ideology and Superstructure 46-50.

105 Marx K A Contribution to the Critique of Political Economy 20. 
mode of production, by the totality of the social relations of production is meant, therefore, the articulation of commodity production and commodity exchange.

The point is that the Preface does not admit of the conclusion that, for Marx, the origins of the legal form are to be sought in the process of production. Nor, it should be observed, does the Preface imply that the genesis of the legal form is not to be found in the process of circulation. In this connection, Marx's materialist "guiding principle", as set out in the Preface, does not specify the relationship between the components of the relations of production. There is, in other words, nothing in the Preface on which the critics may rely to press home the accusation that Pashukanis is mistaken to privilege the circulation component or that he is wrong to derive the legal form from the process of commodity exchange. The criticism that Pashukanis illegitimately elevates exchange above production is presented as a materialist argument derived from Marxist first principles. However, these principles do not include the invariable primacy of production over exchange. And, by extension, they do not exclude the possibility that, in certain circumstances and for certain purposes, exchange may well be prior to production.

The Preface does not engage the legal form analytically. It is useful for situating law in general as a superstructural element and to comprehend its relation to the production process in general, but it does not provide significant insight into the constitution of the legal form. For this we need to look to works such as the Grundrisse and Capital, where Marx does delineate the materialist rudiments of the general theory of law. The most striking feature of Marx's juridical ruminations is the frequency and consistency of the thesis that, of the totality of the relations of production, it is the relations of exchange which provide the material source of the legal form. The extracts from Capital and the Grundrisse cited earlier typify Marx's approach to the legal form. As is evident from the additional extracts quoted below, it is an approach to which Marx had repeated and regular recourse:

The exchange of commodities of itself implies no other relations of dependence than those which result from its own nature. On this assumption, labour-power can appear upon the market as a commodity, 
only if, and so far as, its possessor, the individual whose labour-power it is, offers it for sale, or sells it, as a commodity. In order that he may be able to do this, he must have it at his disposal, must be the untrammelled owner of his capacity to labour, i.e., of his person. He and the owner of money meet in the market, and deal with each other as on the basis of equal rights, with this difference alone, that one is buyer, the other seller; both, therefore, equal in the eyes of the law. ${ }^{106}$

This sphere [of exchange] is in fact a very Eden of the innate rights of man. There alone rule Freedom, Equality, Property and Bentham. Freedom, because both buyer and seller of a commodity, say of labourpower, are constrained only by their own free will. They contract as free agents, and the agreement they come to, is but the form in which they give legal expression to their common will. Equality, because each enters into relation with the other, as with a simple owner of commodities, and they exchange equivalent for equivalent. Property, because each disposes only of what is his own. And Bentham, because each looks only to himself. ${ }^{107}$

[W]hen the economic form, exchange, posits the all-sided equality of its subjects, then the content, the individual as well as the objective material which drives towards the exchange, is freedom. Equality and freedom are thus not only respected in exchange based on exchange values but, also, the exchange of exchange values is the productive, real basis of all equality and freedom. ${ }^{108}$

In Roman law, the servus is therefore correctly defined as one who may not enter into exchange for the purpose of acquiring anything for himself. It is, consequently, equally clear that although this legal system corresponds to a social state in which exchange was by no means developed, nevertheless, in so far as it was developed in a limited sphere, it was able to develop the attributes of the juridical person, precisely of the individual engaged in exchange, and thus anticipate the legal relations of industrial society, and in particular the right which rising bourgeois society had necessarily to assert against medieval society. ${ }^{109}$

Marx may not have written a major treatise on law. But whenever in his economic and political writings he devotes any serious analytical attention to the specificity of the legal form he locates it squarely within the compass of exchange relations. His

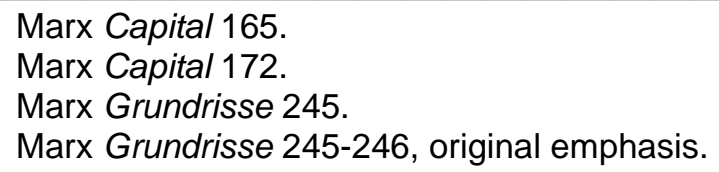


scattered theses on the legal form all reduce to the single proposition that law takes the form it does because it is an expression of the exchange relations of the relations of production. This is made crystal clear in the last extract cited above, in which Marx literally and emphatically equates the "juridical person" with "the individual engaged in exchange".

Engels's legal writings reproduce Marx's position. In this regard it must be recalled that Pashukanis himself cites Engels's submissions on the legal form contained in Anti-Dühring as a source of the general theory. He relies specifically on a chapter entitled Morality and Law. Equality and explains that:

In it, Engels gives an absolutely precise formulation of the link between the principle of equality and the law of value, with the footnote that "this derivation of the modern idea of equality from the economic condition of bourgeois society was first expounded by Marx in Capital". ${ }^{110}$

Indeed, for Engels, ${ }^{111}$ the bourgeoisie subscribed to a world view which was legal in its essentials. As a class, the bourgeoisie was composed of "producers of, and traders in, commodities". ${ }^{112}$ They understood that the "exchange of commodities on the level of society and in its fully developed form" was dependent vitally upon the existence of "universally valid regulations" or legal norms. ${ }^{113}$ This is why "equality before the law became the bourgeoisie's main battlecry" in its struggle "against the feudal lords and the absolute monarchy". ${ }^{114}$ Here we see Engels asserting, exactly as did Marx, that it is in the sphere of commodity circulation that the genesis of the legal form is to be located.

In other words, the founding fathers of Marxism were at one in their comprehension of the legal form as the materialisation of the exchange relations of bourgeois society. Pashukanis's achievement was to perceive the pattern in the pronouncements of Marx and Engels, and to spot the outlines of a theory of law in

\footnotetext{
Pashukanis Law and Marxism 38.

Engels "Lawyers' Socialism" 598.

Engels "Lawyers' Socialism" 597.

Engels "Lawyers' Socialism" 598.

Engels “Lawyers' Socialism" 598.
} 
them. Thereafter, as he himself owns, ${ }^{115}$ it was an easy matter to extrapolate and elaborate the Marxist fundamentals into a coherent Marxist general theory of law.

In the light of the preceding discussion, it hardly can be denied that Pashukanis's position has impeccable Marxist credentials. Even the hostile Korsch, ${ }^{116}$ who is often virulent in his criticism, concedes that:

all these revolutionary ideas put forward by Pashukanis are not actually new, but restore and renew the same ideas expressed by Marx himself, partly by implication, but to a large extent explicitly as well, as many as eighty years ago in his critique of German ldeology, in the Communist Manifesto, and repeated decades later in Capital and the Critique of the Gotha Programme.

In this context the argument that Pashukanis is unMarxist because he foregrounds exchange at the expense of production must be rejected as a trivial one. As demonstrated above, neither Marx nor Engels derived the legal form from the process of commodity production per se. Critics who claim that this is what Pashukanis ought to have done obviously have failed to notice that both Marx and Engels did exactly what Pashukanis did, and that is to anchor the analysis of the legal form in the relations of commodity exchange.

The truth of the matter is that the legal form cannot be derived from the process of production. The Marxist epistemology does not countenance a production-centred derivation, for the reasons which follow. Production is a necessary and natural human activity. It is the prime condition of human existence. Human history is the history of successive modes of production. Production preceded the emergence of law and, in the long view of history, will survive the demise of law. ${ }^{117}$ Law is an attribute of a determinate stage in the development of production, namely the stage

\footnotetext{
Pashukanis Law and Marxism 38-39.

Korsch "Appendix" 190.

The idea that law is an aboriginal and eternal feature of human society is a popular piece of bourgeois idealism. Of course, this is to be expected from a class whose rise was synchronous with the rise of the legal form. The bourgeoisie cannot admit of the historical specificity of law without admitting of its own historical transitoriness. Hence its mythologising of the legal form as
} a universal. See Pashukanis Law and Marxism 144. 
at which production becomes infused with the ethos of exchange. This is the epoch of generalised commodity production. It is the epoch in which the raison d'etre of production becomes exchange. It is the epoch in which the production process itself is premised upon the constant sale and purchase of labour-power, that is, the constant exchange of the only value-producing commodity. The point is that the legal form emerges when production is no longer natural, when it has become production for exchange. And the legal form expresses this transformation in the nature of production, from use to exchange. Indeed, the legal form becomes necessary precisely when this transformation occurs. It stipulates the transformation. ${ }^{118}$

The legal form must needs be derived from the exchange relationship. It is called into existence by the transformation from the natural to the commodity economy. That transformation is characterised by the establishment of exchange as the new purpose of production. It is entirely appropriate and expected that the analytical interrogation of the legal form should proceed from this historical fact. Law as we know it did not exist before the exchange economy. It is sensible to look to the new relations of exchange to comprehend the new legal relations which were generated by them. Indeed, there was no other rational basis on which to delimit the legal form. Any attempt to derive it from the process of production was doomed to failure unless it comprehended that that process was exchange-driven. As Miéville ${ }^{119}$ puts it, "the legal form is a function of exchange relations".

In the commodity economy, production leads ineluctably to exchange. An exchange relation stands at both the beginning and at the end of the commodity production process. ${ }^{120}$ Generalised commodity production is simply and singularly about exchange. It is the stage in the development of the forces of production in which the motif of production changes from production for use to production for exchange.

\footnotetext{
118 For a kindred and most insightful defence of Pashukanis's deriving the legal form from exchange relations, see Miéville Between Equal Rights 91-93.

119 Miéville Between Equal Rights 97.

120 The process starts with the sale and purchase of labour-power and ends with the sale and purchase of the finished commodity.
} 
Marx and Engels understood this. So did Pashukanis. ${ }^{121}$ That is why they turned to the exchange relation as the premise of their analysis of the legal form. And that is why the charge that Pashukanis is unMarxist for elaborating a so-called commodity exchange theory of law is a spurious one.

There is a connection between the charge of abstractness and the allegation of methodological waywardness in that the force of abstraction is a vital element of the method used by Pashukanis to construct the general theory. The exchange relation is the commodity relation purified. The sphere of circulation is the site at which the true nature of the commodity is to be comprehended, free of non-economic diversions or distractions. Capitalist relations of production are invariably demarcated in terms of an articulation of economic and non-economic features. The analysis of the legal form needs to abstract from the non-economic features of the economic structure. The process of abstraction led Pashukanis, as it did Marx and Engels before him, to the exchange relation as the unencumbered source of the legal relation and hence as the key to the analysis of the legal form. The process of abstraction enabled him to set aside those aspects of the relations of production which do not advance the comprehension of the legal form, and to identify the exchange relation as the core relation in the delimitation of this form.

The "abstractness" of the general theory is, in this connection, not only unavoidable but necessary. Pashukanis needed to set aside all factors which would have contaminated the integrity of the exchange relation and hence detracted from his theoretical project. A general theory of law cannot be sidetracked into the day-to-day struggle between classes, including the struggle, under capitalism, between the proletariat and bourgeoisie over the extraction of surplus value. It cannot even be concerned about the class composition of the legislature or the class prejudices of

121 This is why Pashukanis Law and Marxism 119 readily qualifies his discussion of the relationship between the commodity and legal forms with the remark that: "All of this presupposes the appropriate level of development of the productive forces". The issue for him was not if the legal form should be derived from production or exchange. The real issue was that the legal form emerges with the break-up of the natural economy, when the forces of production have developed to the stage where production becomes production for exchange. 
the judiciary. It needs to be located at a level of abstraction which will facilitate a materialist explanation of the existence of and need for the legal form itself. That is why Pashukanis had to work at the "rarefied" level of exchange relations, where the commodity subsists in its ideal milieu, unimpeded by social and political device and relying upon human intervention only as the motor of its own movement.

It has been noted already that Pashukanis himself never referred to his theory as the commodity exchange theory or the commodity form theory of law. These are descriptions invented by commentators. As a Marxist, he knew that the legal form had to be derived from the relations of production (and not from the process of production). ${ }^{122}$ And, by employing the force of abstraction, he was able to isolate the exchange aspect of the relations of production as the true material source of the legal relation and to delineate the legal form as a historically specific form which could be comprehended only as the necessary non-economic expression of the commodity form.

Pashukanis thus was entitled to claim to have discovered the structure of a general theory of law which was true to the materialist conception of history discovered by Marx and Engels. His submission that the legal relation is stipulated by the exchange relation is the conclusion which he reached in his quest for a general theory of law informed by the principles of the materialist conception of history. His detractors routinely ignore the method he used to reach his conclusion. They tend to start their critique were he ends his investigation, and then claim that he is unMarxist for supposedly considering exchange to be prior to production. Any serious reader of Law and Marxism knows that the critics have done Pashukanis an unwarranted injustice. The general theory was constructed according to the first principles of the Marxist methodology and the conclusions reached, albeit distasteful to many (as is the case invariably with so many Marxist positions), are entirely plausible and defensible within the Marxist paradigm. ${ }^{123}$

\footnotetext{
122 The parenthetical reminder is necessary because the critics seem to have reduced the relations of production, which is a binary of production and exchange, to the singularity of production.

123 It is remarkably ironic that one of the most sympathetic appreciations of Pashukanis comes from
} 


\subsection{Capitalist law or pre-capitalist law?}

The fourth criticism of Pashukanis, derived from the third, is that he understood law to be a specifically capitalist phenomenon and hence denied the existence of law in pre-capitalist social formations. Warrington's ${ }^{124}$ statement of the issue is representative:

Pashukanis held that law was a peculiarly capitalist problem. This is a result of his commodity form theory. As Pashukanis defined all law as merely the outgrowth of the exchange of commodities, it follows that to be consistent, social arrangements prior to the commodity form of society were not legal.

Head $^{125}$ agrees that Pashukanis tried "to deny that the legal form arose before capitalism" and expresses the opinion that the problems attendant upon such denial "cannot be overcome simply by suggesting that embryonic legal forms existed in earlier epochs". This is a comparatively minor criticism when set against the first three and need not occupy us unduly. However, once again the critics have misunderstood Pashukanis.

The capitalist mode of production is the apotheosis of the commodity economy. Capitalism is generalised commodity production. The beginnings of the legal relation may be perceived in the milieu of petty commodity production. But it is only with the advent of generalised commodity production that we see the development of the legal relation proper, that is, the development of the relation founded upon the

the non-Marxist Fuller 1949 Michigan $L R$ 1159, who has the following to say of Law and Marxism: "In this short book Pashukanis expounds with clarity and coherence an ingenious development of Marxist theory that has been called the 'Commodity Exchange Theory of Law'. His work is in the best tradition of Marxism. It is the product of thorough scholarship and wide reading. It reaches conclusions that will seem to most readers perverse and bizarre, yet in the process of reaching these conclusions it brings familiar facts of law and government into an unfamiliar but revealing perspective. It is the kind of book that any open-minded scholar can read with real profit, however little he may be convinced by its main thesis".

124 Warrington "Pashukanis and the Commodity Form Theory" 59. See also Stone 1985 Law and Society Review 43 and Collins Marxism and Law 110-111.

125 Head Evgeny Pashukanis 215. 
perfect equality of all legal subjects. While the existence of a pre-capitalist legal subjectivity may be granted, it was rudimentary and fragmentary, and did not include equality before the law. Marx ${ }^{126}$ has this to say:

Equality and freedom presuppose relations of production yet unrealised in the ancient world and in the Middle Ages.

Pashukanis ${ }^{127}$ adds that with primitive peoples "it is difficult to distinguish law from the total mass of normative social phenomena" and that "even in medieval Europe only embryonic legal forms existed".

Law is a product of social evolution and is an attribute of all social formations which have developed class divisions. However, mature law is bourgeois law, that is, the law of the bourgeoisie as the ruling class. Bourgeois law is, in this regard, the highwater mark of legal evolution. It is the culmination of law as form. Only in bourgeois society does the juridical outlook triumph completely. Only in bourgeois society are the social relations of production articulated in legal terms. Only in bourgeois society are human relations fully structured according to the principle of legal subjectivity. ${ }^{128}$

The juridical person was, at best, an infans in the world of petty commodity production and undeveloped exchange. Legal subjectivity, in this connection, may indeed be understood as a specifically capitalist phenomenon. Its development was prescribed by the structural requirements of the development of the capitalist mode of production. Thus, Pashukanis ${ }^{129}$ writes that:

in bourgeois society, in contrast to societies based on slavery and serfdom, the legal form attains universal significance, legal ideology becomes the ideology par excellence, and defending the class interest of the exploiters appears with ever increasing success as the defence of the abstract principle of legal subjectivity.

$126 \quad$ Marx Grundrisse 245.

127 Pashukanis Law and Marxism 58.

128 See Pashukanis Law and Marxism 40-45.

129 Pashukanis Law and Marxism 45. 
The "juridical moment of the Person" identified by Marx is thus a specifically bourgeois moment. It is emblematic of the generalisation of commodity production, the destruction of the natural economy and the victory of capitalist social relations of production.

The juridical person comes of age with the capitalist mode of production. ${ }^{130}$ Law, then, is the most immediate superstructural conjugate of the social relations of production of the commodity economy. And legal subjectivity is the animus of the commodity relation. The following explanation by Norrie ${ }^{131}$ sets matters right and disposes of Warrington's allegation easily:

Pashukanis did not say that there was no law in the middle ages. He said that there was no conception of the abstract legal subject but that there were "embryonic legal forms" in existence at that time. Thus Pashukanis did not say that law was a peculiarly capitalist problem. What he said was that law in its purest and most developed form ... was a peculiarly capitalist phenomenon.

It must be noted here, contra Head, that Pashukanis did not concede the existence of embryonic legal forms in the pre-capitalist era simply as a manoeuvre to rescue or reinforce his basic argument that the legal form is a quintessentially capitalist relation. As a Marxist of the classical school, Pashukanis ${ }^{132}$ embraced the notion of social evolution. His identification of the legal form with the capitalist mode of production is informed by such evolutionism, in the sense that the legal form did not emerge fully-fledged and that it went through a necessary process of evolution which commenced in the pre-capitalist era and culminated under capitalism. In other words, Pashukanis's contention that law proper is bourgeois law is derived from the

According to Pashukanis Law and Marxism 61, the demise of the juridical person will mirror the demise of the capitalist mode of production.

131 Norrie 1982 International Journal of the Sociology of Law 430, original emphasis.

132 Reed Woman's Evolution 466 defines social evolutionism as the "theory that society has passed through successive stages of development from lower to higher". From the Marxist perspective, social evolution is comprehended materialistically, according to the historical development of the forces of production and the impact of such development upon the development of human culture and social life. In other words, Marxism accepts that the history of humankind displays a general progression from lower to higher stages of social organisation, with each such stage corresponding to a definite mode of production. 
real history of the development of the legal form. Certainly, it is embarrassingly obvious that the legal form could not have existed as a mature form since time immemorial. Pashukanis has done nothing more than to identify the capitalist epoch as the epoch in which the legal form reaches maturation and, hence, in which law proper makes its appearance on the historical stage.

This is a dimension of Pashukanis's argument which is not especially complicated or obscure. It is completely accessible to anyone who has a mind to engaging it. Certainly, Fuller has no difficulty whatsoever with understanding fully this aspect of the general theory. He states:

In truth, the only law is bourgeois law. To be sure, legal institutions in embryo can be found in a feudal or slave society, where they are intertwined with religious and military elements. Modern scholars are likely to misinterpret these rudimentary legal elements in a pre-capitalist society as the equivalent of modern law. Actually, these embryonic and undifferentiated legal elements are like the first tentative gropings toward a capitalistic organisation that can be detected in even the most primitive societies. The full inner logic of the conception of law can assert itself only under capitalism. ${ }^{133}$

It is revealing surely that a non-Marxist should understand Pashukanis on this issue without difficulty, while so-called Marxist critics seem to founder, ending up attempting to present their own failure to comprehend Pashukanis as a failure in comprehension by Pashukanis.

\subsection{The generality of the general theory?}

The argument that the general theory of law is not really a general theory of law is integral to the assault upon Pashukanism. It is a powerful charge which, if meritorious, would negate much of Pashukanis's achievement and, thereby, the advances in the Marxist analysis of the law which it represents. The argument that the general theory, in fact, is a sectional theory of law has two versions. The first version posits that whereas the general theory may have been adequate for the

133 Fuller 1949 Michigan LR 1161. 
epoch of competitive capitalism it is unable to comprehend the impact of the transition to monopoly capitalism upon the legal form. The fundamental point is that the material changes in the constitution of the capitalist mode of production have deprived the general theory of whatever generality it may have possessed initially. In other words, it has been rendered obsolete by the flux of time. ${ }^{134}$ The second version asserts that the general theory was never right, that it was flawed from its inception. Here the fundamental argument is that the general theory, in fact, always was a sectional theory of law, in the sense that it was always valid for only a section of the law, namely private law. Proponents of this version contend that the general theory was never capacious enough to comprehend legal transactions which fall outside the ambit of private law, and that it thus is cursed with a congenitally fatal flaw.

Miéville $^{135}$ has disposed of the first version of this anti-Pashukanist postulate convincingly and skilfully. Thus it need not detain us any further, except to record a concurrence with Miéville's ${ }^{136}$ submission that: "To say that Pashukanis was once right but is no longer ... is to say that he was never right". In other words, when it is unpacked the first version emerges as a variant of the second version. The rest of this section thus will focus upon the second version, that is, upon countering the argument that the general theory was ab initio general in name only.

Warrington ${ }^{137}$ leads the charge on this front and has the following to say about the "general" aspect of the general theory:

Pashukanis's theory is really concerned with private law and the chapter on criminal law is only added to attempt a spurious theoretical consistency. Pashukanis merely tries to apply his commodity form theory

134 See Miéville Between Equal Rights 101-103 for a more comprehensive explanation of this version of the attack upon the generality of the general theory. Binns 1980 Capital and Class 100 links this charge to the charge of abstraction, arguing that: "[T]he real power of his analysis is in abstraction, in locating the source of what he refers to as the 'legal form'. But he never brings his theory back down to earth again, and this lack of concreteness prevents him understanding the role of law as capitalism itself develops and changes. He leaves us with a view of law under capitalism as an unchanging category instead of as an evolving process".

Warrington "Pashukanis and the Commodity Form Theory" 62. 
which had a certain logical force for private law, to criminal law, where in the formulation of Pashukanis at least, it clearly has no place.

He goes on to dismiss the theory of equivalent punishment as "faintly comic". For Warrington, then, the general theory is actually a theory of private law onto which criminal law has been grafted somewhat artificially.

Hunt weighs in against Pashukanis in similar vein, arguing that the attention which he gives to the class nature of the criminal law means that Pashukanis bifurcates his theorisation of the law between public/criminal and private/civil. He considers that Pashukanis:

introduces a sharp polarity between two modes of law, the criminal law as a means of securing class domination and the civil law as the mechanism governing the exchange relations between atomised legal subjects. ${ }^{138}$

The implication of such an alleged dualism is, of course, that the fit between the socalled commodity form theory of law and the criminal law is, at best, an awkward one. Indeed, it would appear from Hunt's perspective that the criminal law is not subsumed within the homology between the legal form and the commodity form, and hence that the general theory is not really general after all.

Pashukanis always made it clear that the historical basis of the general theory is private law, specifically the law of contract. The legal form itself is first posited as a contract between two legal subjects. The law of contract is the branch of law which is both the historical and logical repository of the notion of equivalence, ${ }^{139}$ which Pashukanis ${ }^{140}$ classifies as the "first truly juridical idea". By contrast, the criminal law appears to be far removed from the compositional fundamentals of the legal form. There is seemingly no natural connection, as there is with private law, between criminal law and the notion of equivalence. However, the apparent disjuncture

Hunt Explorations in Law and Society 81.

See Pashukanis Law and Marxism 121.

Pashukanis Law and Marxism 168. 
between crime and commodity is resolved with Pashukanis's theorisation of crime as a particular form of contract. He postulates that a crime is a retrospective contract.

Felony can be seen as a particular variant of circulation, in which the exchange relation, that is the contractual relation, is determined retrospectively, after arbitrary action by one of the parties. ${ }^{141}$

The party who has taken the arbitrary action is the offender. The offender does not wish the contract. He intends his conduct to be free of any obligations for himself. He wishes a one-sided relation, from which he is the sole beneficiary and in terms of which the victim is an utter loser. The criminal law intervenes to abolish the privilege of asymmetry claimed by the offender. The state impresses him into a contract after he already has had his satisfaction. Faced with the might of the state, he is forced to keep his side of the bargain and render performance to his victim. By committing his crime the offender has violated the principle of equivalence which defines all things juridical. The criminal law exists to reinstate this juridical prime directive whenever it has been so infracted.

Warrington and Hunt are mistaken in their efforts to vilify the general theory as sectional. The principle of equivalence is foundational to the commodity economy and hence to the nature of bourgeois justice. As the principle which stipulates the commodity and legal forms and their interrelation, it is a centrepiece of the general theory of law. It thus also governs the comprehension of crime and punishment. When Pashukanis ${ }^{142}$ defines a crime as a retrospective contract, he is invoking the principle of equivalence. $\mathrm{He}$ is doing the same when he analyses punishment as an exchange transaction. In other words, criminal justice is about equivalent requital. For Pashukanis, then, the principle of equivalence is a theoretical imperative. His general theory stands and falls by it.

Certainly the principle of equivalence, as applied by Pashukanis himself, is able to

\footnotetext{
141 Pashukanis Law and Marxism 168. Melossi and Pavarini The Prison and the Factory 2 refer to this formulation as "the famous thesis of Pashukanis".

142 See Pashukanis Law and Marxism 179-183.
} 
rebuff easily the allegation by Warrington that the commodity form theory of law is, in reality, a theory of private law which has nothing sensible to say about the field of public law. In any event, Norrie ${ }^{143}$ has shown conclusively that it is Warrington's argument which is spurious. It also bears noting here that Stone, who, unlike Norrie, is no friend of Pashukanis, finds nothing wrong with or comic about his analysis of criminal law. Indeed, he believes that Pashukanis's "views on criminal law are insightful" and submits that they "may be analogised to many other areas of law". ${ }^{144}$

Hunt's position, too, is untenable and reduces to nothing more than assertion. Pashukanis's is a general theory of law and at no point does he hint even at the polarity which Hunt espies. Certainly, the fact that the criminal law is readily available as a weapon of bourgeois class rule, even terror, by no means implies its exclusion from the ambit of the general theory. The making of such a connection is not entailed even in the postulates of formal logic. What is readily implied, however, is that the criminal law, as suggested by Jakubowski, ${ }^{145}$ harnesses the power of the state "to execute and protect private or civil law". In other words, whereas the criminal law may have had very little to do with the production of the legal form, it is imbricated comprehensively in the reproduction of that form.

The legal form summates in the Rechtsstaat, which may be comprehended as the exemplar of "market relations among formally free and equal individuals", ${ }^{146}$ and the criminal law is its most conspicuous guarantor. Whatever schism exists between private law and the criminal law is of Hunt's making, not Pashukanis's. He understood a crime to be a variant of a contract, and therefore considered the criminal law to be as readily incorporated into the general theory as the law of contract. ${ }^{147}$ The criminal law may be possessed of a special status as the branch of

\footnotetext{
143 Norrie 1982 International Journal of the Sociology of Law 432-434.

144 Stone 1985 Law and Society Review 44-45.

145 Jakubowski ldeology and Superstructure 49.

146 Jessop The Capitalist State 85.

147 This also makes nonsense of the subsequent argument by Hunt Explorations in Law and Society 81 that in an attempt to overcome the alleged dualism between private and criminal law, Pashukanis "subsumes his attempt to theorise state and criminal law into a theory of punishment". His theory of punishment is neither more nor less than a theory of punishment, and one which is entirely consonant with his general theory of law.
} 
law which is most obviously associated with the coercive competence of the bourgeois state, ${ }^{148}$ but that status does not entail a qualitative difference from private law or from the other branches of public law. And certainly it does not disqualify the criminal law as a component of the legal form to be comprehended under Pashukanis's general theory of law.

The point is that Pashukanis ${ }^{149}$ always conceived his theory as properly general and hence applicable to the legal form in all of its manifestations, including all of its public law manifestations. Lipson ${ }^{150}$ sums up Pashukanis's position on the matter cogently:

He maintained ... that law as a general form - not merely piece by piece, but as a general form - was linked in history to that economic relationship that he said Marx said was at the bottom of all societies that obtained in the interval between the end of primitive family subsistence and the beginning of true socialism: namely, the relationship of commodity exchange.

For Pashukanis, then, the homology between the commodity form and the legal form is valid also for criminal law, ${ }^{151}$ that is, the notion of equivalence, which is a structural feature of every contract, is also a structural feature of every crime. ${ }^{152}$

In the end, however, the general theory cannot be adjudged according to the empiricist criterion of the number of branches of law it may or may not encompass. In the realm of theory, generality is not a function of quantity. In other words, the question is not whether the general theory can account for the various branches of law in all their diversity. Rather, it is whether the general theory can account for the

\footnotetext{
148 Of course, all branches of law rely ultimately upon state violence (or the threat thereof) for their efficacy.

149 See Pashukanis Law and Marxism 40.

150 Lipson "Is there a Marxist Theory of Law?" 192. See also Norrie 1982 International Journal of the Sociology of Law 434 who finds "good grounds for taking seriously Pashukanis's claim that his is a general theory of law, and not one illicitly generalised from private civil law".

151 Jakubowski Ideology and Superstructure 49, who adheres to Pashukanis's central arguments, holds that: "Public law regulates the relations between the state and public institutions, and between these and the citizens; it serves to execute and protect private or civil law by means of the power of the state. The foundation of all these relations is still legal subjectivity and the recognition of the legal capacity of man, which give the relations of domination a general form."

152 See Arthur "Editor's Introduction" 15, Stone 1985 Law and Society Review 44 and Jakubowski Ideology and Superstructure 49.
} 
existence of the legal form itself. In order to do so, it must elaborate those concepts which give law its law-ness or legal-ness. ${ }^{153}$ Pashukanis himself understood his task in those terms. In this connection he tells us that:

The general theory of law may be defined as the development of the most fundamental and abstract juridical concepts, such as "legal norm", "legal relation", "legal subject" and so on. Since these concepts are abstract, they are applicable to each and every branch of law; regardless of the concrete content to which they are applied, their logical and systematic meaning remains constant. ${ }^{154}$

What is evident immediately from this definition is Pashukanis's concern with law as a genus. He was not especially interested in the concretisation of the legal form in contract law, criminal law, constitutional law, family law, and so forth. To be sure, his investigations led to his identifying the contract as the aboriginal legal transaction. But that did not mean that the general theory was in fact a theory of contract law and, thereby, circumscribed within private law. In terms of legal evolution, private law may have enjoyed historical precedence over public law. However, Pashukanis did not equate historical precedence with theoretical primacy. His project was to theorise law qua form. It was not to demonstrate that every branch of law may be derived directly or even indirectly from the commodity form. It was to demonstrate the fundamental proposition that the legal form per se is the derivative of the commodity form. ${ }^{155}$

The argument that the general theory is a theory of private law or that it illegitimately separates private from public law is misinformed. Pashukanis sought to excavate the material foundations of the legal form itself, to interrogate the fundamental legal concepts founding all the branches of law, whether public or private. The fact that he derived the general theory from contract does not and cannot mean that it is a sectional theory of law. The method of historical materialism led Pashukanis to single

\footnotetext{
$153 \quad$ See Miéville Between Equal Rights 83 \& 103.

154 Pashukanis Law and Marxism 47.

155 See Head Evgeny Pashukanis 228, who reminds us, correctly, that "Pashukanis argued that the legal form, not every precise aspect of its content, was rooted in commodity exchange and production".
} 
out contract as the universal equivalent ${ }^{156}$ of legal relations. His detractors seek to subvert the general theory by reducing it to its point of departure in private law. However, that is analytical errantry which attests only to the failure of the detractors, wilful or otherwise, to appreciate the methodological architecture of the general theory.

\subsection{Pashukanism, anarchism and Stalinism}

The charge that Pashukanis was an anarchist or a Stalinist or both, albeit not as popular as the allegations discussed above, is as important for being overtly political. The basic argument, as explained by Beirne and Sharlet, ${ }^{157}$ is that Pashukanis's general theory was:

a left communist, or perhaps anarchist, theory which, if implemented, would greatly impede the construction and reproduction of socialist relations of production in the USSR.

Schlesinger ${ }^{158}$ makes the argument thus:

It is not difficult to understand why the Soviets dropped a theory which could only be interpreted as an apology either for capitalism or for lawlessness, in the sense of anarchy or arbitrary rule.

Pashukanis, it would appear, is deemed by some to be the theoretician of a kind of lawless anarchy in Bolshevik Russia. This is a line of criticism which was championed by Vyshinsky, ${ }^{159}$ who was to become Stalin's chief prosecutor in the murderous Moscow Trials, and it is linked directly to Pashukanis's liquidation as a supposed enemy of the people in $1937 .{ }^{160}$

\footnotetext{
See Marx Capital 90.

Beirne and Sharlet "Introduction" 23.

Schlesinger R Soviet Legal Theory 164.

Vyshinsky The Law of the Soviet State 53-57.

Hazard 1954 American Journal of International Law 385-386 says of Pashukanis's liquidation: "No overt act of treachery was disclosed. He was criticised primarily for having preached a philosophy of law which, had it been followed to its conclusions, would have undermined the foundations of the Soviet state, and it was hinted that his theory had been developed for the purpose of bringing about the end of the Soviet system of government".
} 
This criticism does not stop with the charge of anarchism. It goes further, to implicate Pashukanis and his general theory in the rise of the very Stalinist regime which liquidated him. Thus, for example, Beirne and Sharlet ${ }^{161}$ argue that his theory entailed a legal nihilism which subjected the judicial process to political ends and which "inevitably contributed to the growth of a jurisprudence of terror" so characteristic of Stalinism. Head concurs with Beirne and Sharlet, declaring that their "indictment was justified". And he goes further, to allege that "Pashukanis' service to Stalin's regime began earlier - back in 1924-25", 162 and that "key aspects of his theory served the interests of the emerging Stalinist bureaucracy, with whom he aligned himself against the Left Opposition". ${ }^{163}$ According to Head, ${ }^{164}$ then, Pashukanis was already a Stalinist at about the time of the first publication of Law and Marxism. Binns ${ }^{165}$ finds it apt to declare that "Pashukanis was no Stalinist". However, he undoes this declaration immediately with the submission that Pashukanism possesses a "right-wing technocratic streak" which "cut with the grain of Stalinism and against the grain of the Left Opposition". ${ }^{166}$

It is submitted that this criticism is entirely without merit, in both of its aspects. The accusation of anarchism had long ago been disposed of by Stuchka, ${ }^{167}$ who analysed it as a reactionary agitation for bourgeois legal certainty in the turbulence of a proletarian revolution, which revolution necessarily had to smash the legal system and abolish the laws of the bourgeoisie. He insisted that the Bolshevik assault upon bourgeois law did not entail lawlessness and anarchy. The Bolsheviks subscribed to

\footnotetext{
161 Beirne and Sharlet "Introduction" 21-23. See also Warrington "Pashukanis and the Commodity Form Theory" 60.

162 Head Evgeny Pashukanis 163.

163 Head Evgeny Pashukanis 168.

164 Head Evgeny Pashukanis 154 attributes Pashukanis's "unexpected emergence from obscurity" with the publication of Law and Marxism: A General Theory directly "to the fact that he publicly lined up against the Left Opposition as early as 1925". Indeed, Head devotes a large part of chapter 8 of his book to demonstrating that Pashukanis aligned himself with Stalin against Trotsky and the Left Opposition already in the mid-1920s, and that he maintained that position until he himself became a victim of the Stalinist thermidor. Binns 1980 Capital and Class 111.

Binns 1980 Capital and Class 111.

167 See Stuchka "The Old and New Court" 187-188 and Stuchka "Five Years of Revolution in Law" 190.
} 
a revolutionary legality administered by the People's Courts. Thus he declares:

No, we are not anarchists. Quite the contrary. We attribute a great deal of significance to laws, perhaps even too much at the moment, but only to laws of the new order. And those laws correspond to the old laws only insofar as the new order can agree with the atrophying, repudiated order. ${ }^{168}$

The Bolsheviks were Marxists in the classical tradition and were thereby implacable opponents of anarchism. Pashukanis was a Bolshevik and, despite their other differences, shared with Stuchka the Bolshevik commitment to a revolutionary legality.

The charge that Pashukanis's theory of law encouraged the rise of Stalinism is a particularisation of the well-worn argument that Stalinism is the direct heir of Bolshevism and which would blame, for example, Lenin's democratic centralism or Trotsky's internationalism for Stalin's betrayal of the revolution. It is an argument which has to be taken with a pinch of salt, simply because there was nothing Stalinist inherent in the politics of Bolshevism. Pashukanis's theory was, if anything, an impediment to the anti-Bolshevik agenda of Stalinism. This is why he had to be liquidated. Thus Lipson ${ }^{169}$ says:

Whatever the merits of this approach in theory, it could not please the rulers of the Soviet Union, especially in the 1930s: the authorities practising their kind of lawlessness under label of a search for stability were not able to countenance the scholarly justification of the transcendence of law.

Even Warrington, ${ }^{170}$ who is one of Pashukanis's most uncomplimentary critics, discounts this argument, in the following terms:

Some commentators have argued that Pashukanis's attitude paved the

\footnotetext{
168 Stuchka "Proletarian Law" 162. See also Stuchka "Five Years of Revolution in Law" 190: "Of course, the Bolsheviks did not reject the significance of laws. They perhaps even believed in them too much".

169 Lipson "Is there a Marxist Theory of Law?" 193-194.

170 Warrington "Pashukanis and the Commodity Form Theory" 60-61.
} 
way for Stalinism. But Pashukanis tried, however inadequately, to produce a theory that would reach beyond the confines of the restraints of all forms of legality. It seems a little unfair to blame Pashukanis's theory for the terror that followed merely because Pashukanis himself was politically inept, and later even wilfully blind. Only by assuming that if a society shakes off the need for law that it must then regress to a dark age is it possible to see Pashukanis's General Theory as a step towards arbitrary power.

Pashukanis was neither a crypto-anarchist nor a latent Stalinist. He was a Bolshevik who elaborated a Marxist general theory of law which embraced a revolutionary legality while anticipating the demise of the legal form in a future classless society.

Needless to say, this conclusion runs counter to the allegations made by Head about Pashukanis's supposedly long-standing Stalinist sympathies. No attempt will be made here to gainsay the evidence produced by Head. However, revolutions and their aftermaths always have casualties, not least from amongst the ranks of the revolutionaries themselves. The Bolshevik revolution was simultaneously worldhistoric and fragile, and the subsequent betrayal of the revolution by the Stalinists claimed the lives of thousands of men and women who had dedicated their lives to the cause of revolution. Head ${ }^{171}$ himself acknowledges this fact when he writes that:

\begin{abstract}
Pashukanis' unedifying capitulation to the requirements of Stalin's order was not simply an individual question. Far more prominent figures, who had played a leading role in the 1917 Revolution, capitulated to Stalin and eventually issued groveling confessions to have committed all manner of "counter-revolutionary" crimes in ultimately futile attempts to avoid execution in the show trials of the late 1930s. Among them were Zinoviev, Kamenev, Bukharin, Rykov, Radek and Piatakov. Their ludicrous confessions, after life-long dedication to the cause of socialism, to have functioned as agents of fascism were the end-product of years of political and theoretical backtracking, self-criticisms and humiliations in order to prove their devotion to the Soviet state.
\end{abstract}

Pashukanis was but one of a large number of Bolsheviks unable to resist the Stalinist rampage through the ranks of the revolution. To be sure, he had none of the self-sacrificing heroism of Trotsky and so many other Left Oppositionists. He may

171 Head Evgeny Pashukanis 249. 
have tried to avoid the wrath of the Stalin regime with sorry assaults upon the Left Opposition and with even sorrier attempts to revise his general theory to appease the Stalinists. Yet, as Milovanovic ${ }^{172}$ notes, "his essential position concerning the homology between the legal form and the commodity form remained intact to the end". And as Head ${ }^{173}$ observes, his "refusal to abandon the ultimate goal of the disappearance of the legal form became incompatible with Stalin's purposes". In other words, Pashukanis never did abandon the tenets of classical Marxism upon which he had constructed his general theory. What is more, his persistent rejection of the notion of proletarian law ${ }^{174}$ was an eminently Left Oppositionist position, mirroring Trotsky's own rejection of the idea of proletarian culture. ${ }^{175}$

The point is that, despite his political capitulation to Stalinism, Pahukanis's general theory of law was sufficiently anti-Stalinist to cost him his life. Perhaps this is why Vyshinsky, Stalin's prosecutorial hit-man, denounced Pashukanis as a Trotskyist. ${ }^{176}$ Pashukanis was as much a victim of the Stalinist betrayal of the Bolshevik revolution as were the Left Oppositionists. The major difference is that Pashukanis did not have the personal courage and political commitment of the Left Oppositionists to adopt and defend an anti-Stalinist position. However, his political and personal failings do not constitute a rational basis upon which to reject his general theory of law which, objectively assessed, was a product of revolution, not reaction.

\section{Conclusion}

Pashukanis needs defending. Despite his desperate efforts to avoid Stalin's assassins, in the end he paid with his life for his elaboration of the general theory of law. Notwithstanding his pitiable attempts at recantation, he was unable and unwilling to forgo the Marxist fundamentals upon which the general theory was founded. He was a dyed-in-the-wool Marxist for whom the imprint of the revolution

\footnotetext{
Milovanovic "Introduction" xiv. Head Evgeny Pashukanis 164.

See Pashukanis Law and Marxism 61, Warrington "Pashukanis and the Commodity Form Theory" 59-61 and Head Evgeny Pashukanis 163.

175 See Trotsky Literature and Revolution 184- 214.

176 See Milovanovic "Introduction" xxi.
} 
was ineradicable. If he did not die a revolutionary, he had to die because he had fashioned and clung onto a theory of law which was revolutionary. Marx and Engels had discovered that the key to understanding the legal form lay in its relation to the commodity form. Pashukanis gave their discovery the methodological rigour it needed to become the Marxist theory of law. In this connection Balbus ${ }^{177}$ makes the perceptively telling observation that:

Almost all subsequent Marxist work on the law is, unfortunately, a regression from the standard established by Pashukanis's pioneering effort.

This essay has sought to defend Pashukanis against his neo-Marxist opponents, those who, contra Balbus, would classify the general theory as unMarxist, as a regression from the pioneering efforts of Marx and Engels. And unlike other defences of Pashukanis, ${ }^{178}$ this has been an attempt to prove, without concessions, that all the specified objections to the general theory are rebuttable. The general theory was forged in the bosom of the first proletarian revolution in human history, on the basis of the self-same theoretical and analytical principles which had shaped that revolution. Its fate was linked intimately, therefore, to the fate of the revolution. Pashukanis's self-denigrating attempts to appease the Stalinist reaction were of no avail precisely because the general theory was one of the products of the revolution which Stalin was betraying systematically. The victory of Stalinism required the death of both the general theory and its author.

However, truly Marxist constructions do not succumb readily to the forces ranged against them. Pashukanis's general theory of law hitherto has outlived all efforts, political and intellectual, to render it nugatory. The allegations which constitute the subject matter of this essay represent the endeavours of latter-day new leftists to kill off the general theory yet again. The aim has been to demonstrate that each and every charge against Pashukanism traversed in this essay is invalid. None of the

Balbus "Commodity Form and Legal Form" 88.

178 See, for example, Norrie 1982 International Journal of the Sociology of Law and Miéville Between Equal Rights. 
anti-Pashukanist allegations here considered withstands scrutiny from the perspective of classical Marxism. Upon close inspection, all of them pale against the revolutionary achievement of Pashukanis, and tend more to cavilling than criticism. It will be recalled that Pashukanis's ambition was to elaborate a general theory of law on the basis of "the development of the most fundamental and abstract juridical concepts". ${ }^{179} \mathrm{He}$ achieved this ambition with considerable aplomb by deploying and staying true to the first principles of classical Marxism. If there is a definitive Marxist theory of law, it is Pashukanis's. This essay is presented as a settling of accounts with those who would demur.

179 Pashukanis Law and Marxism 47. 


\section{Bibliography}

Alexander An Ordinary Country

Alexander N An Ordinary Country: Issues in the Transition from Apartheid to Democracy in South Africa (University of Natal Press Pietermaritzburg 2002)

Anderson Passages from Antiquity to Feudalism

Anderson P Passages from Antiquity to Feudalism (Verso London 1981)

Arthur "Editor's Introduction"

Arthur C "Editor's Introduction" in Pashukanis E Law and Marxism: A General Theory (Ink Links London 1978) 9-31

Balbus "Commodity Form and Legal Form"

Balbus I "Commodity Form and Legal Form: An Essay on the Relative Autonomy of Law" in Reasons C and Rich R. The Sociology of Law: A Conflict Perspective. (Butterworths Toronto 1978) 73-90

Balibar "The Basic Concepts of Historical Materialism"

Balibar E "The Basic Concepts of Historical Materialism" in Althusser L and Balibar E Reading Capital. (New Left Books London 1970) 199-308

Beirne and Sharlet "Introduction"

Beirne P and Sharlet R (1979) "Introduction" in Evgeny Pashukanis: Selected Writings on Marxism and Law (Academic Press London 1980) 1-36

Binns 1980 Capital and Class

Binns P "Review Article: Law and Marxism" 1980 Capital and Class 100-113

Butler Soviet Law

Butler W Soviet Law (Butterworths London 1988) 
Collins Marxism and Law

Collins H Marxism and Law (Oxford University Press Oxford 1984)

Davis "Legality and Struggle"

Davis D "Legality and Struggle: Towards a Non-Instrumentalist View of Law" in Corder H (ed) Essays on Law and Social Practice in South Africa (Juta Cape Town 1988) 65-92

Engels "Speech"

Engels F "Speech at the Graveside of Karl Marx" in Tucker R (ed) The MarxEngels Reader (WW Norton \& Company New York 1978) 681-682

Engels "Lawyers' Socialism"

Engels F "Lawyers' Socialism" in Marx K. and Engels F. Collected Works: Volume 26 (Lawrence \& Wishart London 1990) 597-616

Fine Democracy and the Rule of Law

Fine B Democracy and the Rule of Law: Liberal Ideals and Marxist Critiques (Pluto Press London 1984)

Fuller 1949 Michigan LR

Fuller L "Pashukanis and Vyshinsky: A Study in the Development of Marxian Legal Theory" 1949 Michigan LR 1157-1166

Gavigan 1981 Canadian Criminology Forum

Gavigan S "Marxist Theories of Law: A Survey, with Some Thoughts on Women and Law" 1981 Canadian Criminology Forum 1-12

Harvey The Limits to Capital

Harvey D The Limits to Capital (Basil Blackwell Oxford 1982)

Hayek Law, Legislation and Liberty

Hayek FA Law, Legislation and Liberty Volume 2: The Mirage of Social Justice $162 / 351$ 
(The University of Chicago Press Chicago 1978)

Hazard 1954 American Journal of International Law

Hazard J "Pashukanis is no Traitor" 1954 American Journal of International Law 385-388

Head Evgeny Pashukanis

Head M Evgeny Pashukanis: A Critical Reappraisal (Routledge-Cavendish Oxford 2008)

Hegel The Philosophy of History

Hegel G The Philosophy of History (Dover Publications New York 1956)

Hirst On Law and Ideology

Hirst P On Law and Ideology (Macmillan London 1979)

Hitchens 2009 The Atlantic

Hitchens C "He's Back: The Current Crisis and the Enduring Relevance of Marx" 2009 The Atlantic 88-95

Hunt Explorations in Law and Society

Hunt A Explorations in Law and Society: Toward a Constitutive Theory of Law (Routledge New York 1993)

Jakubowski Ideology and Superstructure

Jakubowski F Ideology and Superstructure in Historical Materialism (Pluto Press London 1990)

Jessop The Capitalist State

Jessop B The Capitalist State: Marxist Theories and Methods (Martin Robertson Oxford 1982) 
Kelsen The Communist Theory of Law

Kelsen $\mathrm{H}$ The Communist Theory of Law (Stevens \& Sons Limited London 1955)

Korsch "Appendix"

Korsch K "Appendix: An Assessment by Karl Korsch" in Pashukanis E Law and Marxism: A General Theory (Ink Links London 1978) 189-195

Larrain A Reconstruction of Historical Materialism

Larrain J A Reconstruction of Historical Materialism (George Allen \& Unwin London 1986)

Lipson "Is there a Marxist Theory of Law?"

Lipson L "Is there a Marxist Theory of Law? Comments on Tushnet" in Pennock $\mathrm{J}$ and Chapman J (eds) Marxism: NOMOS XXVI (New York University Press New York 1983) 189-195

Lloyd and Freeman Lloyd's Introduction to Jurisprudence

Lloyd of Hampstead and Freeman M Lloyd's Introduction to Jurisprudence (Stevens \& Sons London 1985)

Löwy The Politics of Combined and Uneven Development

Löwy M The Politics of Combined and Uneven Development: The Theory of Permanent Revolution (Verso London 1981)

Makepeace Marxist ldeology and Soviet Criminal Law

Makepeace R Marxist Ideology and Soviet Criminal Law (Croom Helm London 1980)

Mandel Introduction to Marxism

Mandel E Introduction to Marxism (Ink Links London 1979) 


\section{Marx Capital}

Marx K Capital: Volume 1 (Lawrence \& Wishart London 1954)

Marx Grundrisse

Marx K Grundrisse: Foundations of the Critique of Political Economy (Penguin Books Middlesex 1973)

Marx A Contribution to the Critique of Political Economy

Marx K A Contribution to the Critique of Political Economy (Progress Publishers Moscow 1977)

Melossi and Pavarini The Prison and the Factory

Melossi D and Pavarini M The Prison and the Factory: Origins of the Penitentiary System (The Macmillan Press London 1981)

Miéville Between Equal Rights

Miéville C Between Equal Rights: A Marxist Theory of International Law (Brill Leiden 2005)

Milovanovic "Introduction"

Milovanovic D "Introduction to the Transaction Edition" in Pashukanis E The General Theory of Law and Marxism (Transaction Publishers New Brunswick 2002) vii-xxvi

Norrie 1982 International Journal of the Sociology of Law

Norrie A "Pashukanis and the Commodity Form Theory: A Reply to Warrington" 1982 International Journal of the Sociology of Law 419-437

Ollman Dialectical Investigations

Ollman B Dialectical Investigations (Routledge London 1993)

Pashukanis Law and Marxism

Pashukanis EB Law and Marxism: A General Theory (Ink Links London 1978) 
Plamenatz Man and Society

Plamenatz J Man and Society: Volume 2 (Longmans London 1963)

Plekhanov The Materialist Conception of History

Plekhanov G The Materialist Conception of History (Lawrence \& Wishart London 1976)

Reed Woman's Evolution

Reed E Woman's Evolution: From Matriarchal Clan to Patriarchal Family (Pathfinder Press New York 1975)

Sayer The Violence of Abstraction

Sayer D The Violence of Abstraction: The Analytic Foundations of Historical Materialism (Basil Blackwell Oxford 1987)

Schlesinger R Soviet Legal Theory

Schlesinger R Soviet Legal Theory: Its Social Background and Development (Kegan Paul, Trench, Trubner \& Co London 1946)

Schumpeter Capitalism, Socialism and Democracy

Schumpeter JA Capitalism, Socialism and Democracy (Unwin University Books London 1966)

Sparkes Talking Philosophy

Sparkes A Talking Philosophy: A Wordbook (Routledge London 1991)

Stone 1985 Law and Society Review

Stone A "The Place of Law in the Marxian Structure-Superstructure Archetype" 1985 Law and Society Review 39-67

Stuchka "Proletarian Law"

Stuchka P "Proletarian Law" in Rosenberg W (ed) Bolshevik Visions: First Phase of the Cultural Revolution in Soviet Russia Part 1(University of Michigan 
Press Michigan: 1990)

Stuchka "The Old and New Court"

Stuchka P "The Old and New Court" in Rosenberg W (ed) Bolshevik Visions: First Phase of the Cultural Revolution in Soviet Russia Part 1 (University of Michigan Press Michigan: 1990)

Stuchka "Five Years of Revolution in Law"

Stuchka P "Five Years of Revolution in Law" in Rosenberg W (ed) Bolshevik Visions: First Phase of the Cultural Revolution in Soviet Russia Part 1 (University of Michigan Press Michigan: 1990)

Sumner Reading Ideologies

Sumner C Reading Ideologies (Academic Press London 1979)

Sweezy The Theory of Capitalist Development

Sweezy P The Theory of Capitalist Development (Monthly Review Press New York 1942)

Timpanaro On Materialism

Timpanaro S On Materialism (Verso London 1980)

Trotsky Literature and Revolution

Trotsky L Literature and Revolution (University of Michigan Press Michigan 1975)

Tushnet "Is there a Marxist Theory of Law?"

Tushnet M "Is there a Marxist Theory of Law?" in Pennock $\mathrm{J}$ and Chapman $\mathrm{J}$ (eds) Marxism: NOMOS XXVI (New York University Press New York 1983) 171-188 
Vincent 1993 Journal of Law and Society

Vincent A "Marx and Law" 1993 Journal of Law and Society 371-397

Vyshinsky The Law of the Soviet State

Vyshinsky A The Law of the Soviet State (Macmillan New York 1954)

Warrington "Pashukanis and the Commodity Form Theory"

Warrington R "Pashukanis and the Commodity Form Theory" in Sugarman D (ed) Legality, Ideology and the State (Academic Press London 1983) 43-67

Young "Punishment and Social Organization"

Young $P$ "Punishment and Social Organization" in Bankowski $Z$ and Mungham G (eds) Essays in Law and Society (Routledge Direct Editions London 1980) 113-126

\section{Register of internet sources}

Angus Reid Global Monitor 2008 http://www.angus-reid.com

Angus Reid Global Monitor 2008 Europe, US blame capitalism abuses for crisis http://www.angus-reid.com/polls/34157/europe_us_blame_capitalism_abuses_ for_crisis/ [date of use 14 June 2011]

BBC World Service 2009 http://www.worldpublicopinion.org

BBC World Service 2009 Wide dissatisfaction with capitalism - twenty years after the fall of Berlin Wall http://www.worldpublicopinion.org/pipa/articles/ btglobalizationtradera/644.php [date of use 14 June 2011]

Boyes 2008 http://business.timesonline.co.uk

Boyes R 2008 Banking crisis gives added capital to Karl Marx's writings http://business.timesonline.co.uk/tol/business/economics/article4974912.ece [date of use 7 June 2011] 
Connolly 2008 http://www.guardian.co.uk Connolly K 2008 Booklovers turn to Karl Marx as financial crisis bites in Germany http://www.guardian.co.uk/books/2008/oct/15/marx-germanypopularity-financial-crisis [date of use 7 June 2011]

De Santis 2009 http://www.humaniteinenglish.com

De Santis G 2009 Round the world, opposition to capitalism continues http://www.humaniteinenglish.com/spip.php?article1381 [Date of use 14 June 2011]

NBC News 2009 http://worldblog.msnbc.msn.com

NBC News/Bo Gu 2009 Chinese coming back to Marx amid crisis http://worldblog.msnbc.msn.com/_news/2009/04/08/4376532-chinese-comingback-to-marx-amid-crisis [date of use 7 June 2011]

The Economist 2011 http://www.economist.com

The Economist 2011 Public opinion on capitalism: Market troubles http://www.economist.com/blogs/dailychart/2011/04/public_opinion_capitalism [date of use 14 June 2011] 